\title{
OS COMPANHEIROS DE DOM OBÁ: \\ OS ZUAVOS BAIANOS E OUTRAS COMPANHIAS NEGRAS \\ NA GUERRA DO PARAGUAI
}

Hendrik Kraay*

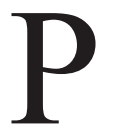

ouco depois de as tropas aliadas atravessarem o rio Paraná e invadirem o sul do Paraguai em abril de 1866, Francisco Otaviano de Almeida Rosa escreveu jubiloso, de Buenos Aires, ao ministro da guerra: "Um abraço pelos nossos triunfos. Vivam os brasileiros, sejam brancos, negros, mulatos ou caboclos! Vivam! Que gente brava!"1 O entusiasmo do diplomata brasileiro pelos feitos militares dos seus patrícios não brancos coloca a questão do impacto da guerra na política racial brasileira. Na época, o Brasil era a maior sociedade escravista nas Américas, com um milhão e meio de homens e mulheres escravizados. Mas pelo menos quatro milhões de afrodescendentes li-

\footnotetext{
Agradeço ao Social Sciences and Humanities Research Council do Canadá pelas bolsas de pesquisa que permitiram a elaboração deste artigo. Trata-se de uma versão consideravelmente ampliada e revisada de "Patriotic Mobilization in Brazil: The Zuavos and Other Black Companies", in Hendrik Kraay e Thomas L. Whigham (orgs.), I Die with My Country: Perspectives on the Paraguayan War, 1864-1870 (Lincoln: University of Nebraska Press, 2004), pp. 61-80. Agradeço os comentários dos pareceristas de Afro-Ásia. As seguintes abreviaturas são usadas nas notas: $A C D$ (Anais da Câmara dos Deputados); AHEx/RQ (Arquivo Histórico do Exército, Requerimentos); AN (Arquivo Nacional), SPE (Seção do Poder Executivo); APEB (Arquivo Público do Estado da Bahia), SACP (Seção de Arquivo Colonial e Provincial), SJ (Seção Judiciária); BN/SM (Biblioteca Nacional, Seção de Manuscritos); $C L B$ (Coleção das Leis do Brasil); OD (Ordem do Dia).

1 Francisco Otaviano de Almeida Rosa a José Antônio Saraiva, Buenos Aires, 24/4/1866, in Francisco Otaviano [de Almeida Rosa], Cartas de Francisco Otaviano, organizado por Wanderley Pinho, Rio de Janeiro: Civilização Brasileira, 1977, p. 159.
} 
vres ou libertos viviam no país e constituíam dois quintos da população total de dez milhões de habitantes. ${ }^{2}$

O significado da grande mobilização militar para essa população afro-brasileira ainda permanece uma questão controvertida, mas relativamente pouco estudada. Decerto, homens negros dominavam as fileiras brasileiras, embora a propaganda paraguaia, que retratava todos os soldados brasileiros como "macacos", exagerasse no seu apelo ao preconceito racial. Para muitos, notadamente o historiador Júlio José Chiavenato, o grande número de homens negros nas fileiras brasileiras evidencia uma política genocida propositalmente executada pelos comandantes que usavam esses soldados como bucha de canhão, especialmente depois do começo do recrutamento sistemático de escravos em fins de $1866 .{ }^{3}$ Outros ecoam a declaração de Otaviano e vêem a guerra como uma experiência racialmente compartilhada que forjou a nacionalidade nos campos de batalha. ${ }^{4}$ A história de Cândido da Fonseca Galvão, mais conhecido como Dom Obá II (o título iorubá por ele adotado no Rio de Janeiro na década de 1880), que serviu numa das companhias de zuavos (compostas de homens negros) criadas na Bahia em 1865-66, revela a complexidade da experiência de guerra para a população negra. Profundamente monarquista, Dom Obá destacava seu serviço ao imperador como evidência do seu pertencimento à nação brasileira, mas também publicava críticas sofisticadas da discriminação racial que ele e o resto da população negra enfrentavam. ${ }^{5}$

Em 1865, todavia, o futuro Dom Obá não passava de uma figura secundária na mobilização dos homens negros na Bahia e em Pernambuco. Nas capitais das duas províncias, muitas companhias de homens negros, denominadas zuavos, couraças e sapadores, foram organizadas

2 Richard Graham, "Free African Brazilians and the State in Slavery Times", in Michael Hanchard (org.), Racial Politics in Contemporary Brazil, Durham: Duke University Press, 1999, p. 31.

3 Júlio José Chiavenato, Os Voluntários da Pátria (e outros mitos), São Paulo: Global, 1983; Júlio José Chiavenato, O negro no Brasil da senzala à Guerra do Paraguai, São Paulo: Brasiliense, 1980.

4 Marco Antônio Cunha, A chama da nacionalidade: ecos da Guerra do Paraguai, Rio de Janeiro: Biblioteca do Exército, 2000, p. 63, 139, 143.

5 Eduardo Silva, Dom Obá II d'África, o príncipe do povo: vida, tempo e pensamento de um homem livre de cor, São Paulo: Companhia das Letras, 1997. 
em 1865-67. Mais de mil homens marcharam para a guerra usando fardas distintas, identificando-se como defensores negros do Império. Essa ideologia remontava a uma longa tradição, que vinha do período colonial, de serviço à monarquia e ao Estado por parte de homens de cor. A mobilização deles também integrava as redes de clientelismo que os ligavam ao sistema político. A experiência desses soldados, e principalmente a dos seus oficiais, cuja atuação militar pode ser seguida em diversas fontes documentais, revela a complexidade da política racial do Estado brasileiro, que recorreu à mobilização de homens negros, mas não aceitou a identidade racial implícita no ato de organizar companhias negras. A mobilização para a guerra invocou antigas tradições de serviço ao Estado por parte de homens negros, mas o governo e o Exército logo as rejeitaram, abolindo as companhias negras no decorrer do ano de 1866. Depois da guerra, havia pouco espaço para os veteranos negros exigirem a cidadania e, como a maioria dos ex-soldados, eles permaneceriam marginalizados pela sociedade.

Embora seja bem conhecido que o Brasil mobilizou companhias negras no começo da guerra, não há nenhum estudo sistemático da sua organização, composição social ou participação na guerra. Este artigo é baseado em documentação baiana sobre a mobilização e o recrutamento na província, e informações de diversas fontes sobre a atuação militar dos quarenta homens que serviram como oficiais de patente nessas companhias negras (ou que foram promovidos a oficiais depois de terem começado seu serviço como cadetes ou sargentos nas unidades racialmente segregadas). Além de corrigir os muitos equívocos sobre os zuavos repetidos com frequência na literatura acadêmica e popular, este artigo reflete sobre a complexidade da política racial na sociedade brasileira imperial e a visão negra de serviço ao Estado (e de cidadania) estreitamente ligado ao serviço militar.

\section{A mobilização patriótica, 1865-66}

A eclosão da guerra provocou uma onda de patriotismo em todo o país. Na véspera de Natal de 1864, João Batista Calógeras, um funcionário público no Rio de Janeiro, escreveu sobre a "efervescência patriótica" 
que já chegara a "36 graus". "Deus ajude o Brasill", acrescentou preocupado. ${ }^{6}$ Embora esse "patriotismo militante" fosse, como lembra Richard Morse, compartilhado principalmente por "uma elite europeizada", ele se estendeu mais profundamente na sociedade do que muitos historiadores reconhecem, chegando a revelar uma "fibra nova - até então desconhecida - da nacionalidade". ${ }^{7}$ Milhares de homens (e mesmo algumas mulheres) se apresentaram voluntariamente para pegar em armas ou para servir ao país de outras maneiras, enquanto os governos imperial e provinciais foram inundados por doações em espécie e em mercadorias para o esforço de guerra. A criação das companhias negras na Bahia e em Pernambuco fez parte dessa mobilização patriótica maciça.

Para facilitar o recrutamento, o governo imperial criou os Voluntários da Pátria na primeira semana de janeiro de 1865 . Os soldados e oficiais dessas novas unidades serviriam apenas enquanto durasse a guerra, receberiam uma gratificação na hora de assentar praça e soldos mais elevados que os da tropa de linha. Depois da guerra, seriam recompensados com terras em colônias agrícolas e preferência na contratação para o funcionalismo público. Essas condições foram logo estendidas aos guardas nacionais designados para o serviço militar, e nada menos que $75 \%$ dos 91.000 homens alistados (segundo o Exército) tinham direito ao status e aos benefícios dos Voluntários. ${ }^{8}$ Milhares assentaram praça voluntariamente em 1865. Um amanuense da secretaria da tesouraria provincial baiana ingenuamente solicitou três meses de licença com vencimento para participar da guerra contra o "déspota do Paraguai"; o professor público da cadeira primária da freguesia de

6 João Batista Calógeras a Pandiá George Calógeras, Rio de Janeiro, 24/12/1864, in João Batista Calógeras, Um ministério visto por dentro: cartas inéditas de João Batista Calógeras, alto funcionário do império, organizado por Antônio Gontijo de Carvalho, Rio de Janeiro: José Olympio, 1959, p. 175.

7 Richard M. Morse, From Community to Metropolis: A Biography of São Paulo, Brazil, New York: Octagon Books, 1974, pp. 142-43; Eduardo Silva, "O Príncipe Obá, um Voluntário da Pátria”, in Maria Eduarda Castro Magalhães Marques (org.), Guerra do Paraguai, 130 anos depois, Rio de Janeiro: Relume Dumará, 1995, p. 70.

8 Decreto 3371, 7/1/1865; Decreto 3508, 30/8/1865, CLB; "Mappa da força com que cada uma das Provincias do Imperio concorreu para a guerra do Paraguay, segundo os mappas remettidos a esta Secretaria de Estado", in Brasil, Ministro da Guerra, Relatório (1872); Peter M. Beattie, The Tribute of Blood: Army, Honor, Race, and Nation in Brazil, 1864-1945, Durham: Duke University Press, 2001, pp. 173-74. 
São João do Paraguaçu demonstrou mais juízo ao pedir uma licença por tempo indeterminado. Estudantes de medicina serviram voluntariamente nos hospitais de sangue. Muitos dos que se apresentaram faziam parte da pequena "classe média", cujos integrantes tinham ligações estreitas com o Estado, e Calógeras se perguntou o que aconteceria com tais "homens que nunca manejaram um fuzil".

As redes de clientelismo logo produziram "voluntários", à medida que os senhores de terras mobilizaram seus dependentes e marcharam com eles às capitais provinciais, da mesma forma que os levavam às urnas nos dias de eleição. ${ }^{10}$ Um historiador de Pernambuco observa que a maioria dos voluntários daquela província se alistava em grupos, com frequência sob a orientação do patrão. Os que organizavam esses grupos de recrutas esperavam comandá-los. Um major da Guarda Nacional de Curralinho, João Evangelista de Castro Tanajura, prometeu doar lotes de terra nas suas fazendas de gado e nos seus engenhos de açúcar às famílias dos voluntários que se juntassem a ele. Insistiu, todavia, que esses homens só marchariam para a guerra sob o seu próprio comando, o que foi negado pelo presidente da província. Dionísio Cerqueira, na época um jovem cadete, recordou que Tanajura, seu primo, faleceu pouco depois de uma "febre cerebral, causada, decerto, pela decepção amarga de ver seu batalhão dado ao comando de outro, [por] influência política do partido dominante". Um oficial e alguns soldados de outro batalhão de voluntários desertaram ao invés de servir sob as ordens dos oficiais indicados pelo presidente provincial. ${ }^{11}$ Não importa como os Voluntári-

9 Requerimentos de José Jorge Bisucheth e José Jorge Perrucho ao Presidente, [Salvador], ca. 1865, APEB/SACP, maço 3670; Presidente ao Ministro da Guerra, Salvador, 4/8/1865, ANRJ/ SPE/IG1, maço 125, fl. 247; J. B. Calógeras a P. G. Calógeras, Rio de Janeiro, 12/1/1865, in Calógeras, Ministério, p. 197.

10 Sobre as eleições e a mobilização de clientelas para votar, ver Richard Graham, Patronage and Politics in Nineteenth-Century Brazil, Stanford: Stanford University Press, 1990, cap. 5; sobre Pernambuco, ver Márcio Lucena Filho, "Pernambuco e a Guerra do Paraguai: o recrutamento e os limites da ordem" (Dissertação de Mestrado, Universidade Federal de Pernambuco, 2000), pp. 92-3.

11 João Evangelista de Castro Tanajura ao Presidente, Curralinho, 2/2/1865; e Salvador, 21/4/ 1865, APEB/SACP, maço 3669; Dionísio Cerqueira, Reminiscências da Campanha do Paraguai, 1865-1870, Rio de Janeiro: Biblioteca do Exército, 1980, p. 56; Tenente-Coronel Comandante, Segundo Batalhão, Voluntários da Pátria, ao Comandante das Armas, Salvador, 16/5/1865 (cópia), APEB/SACP, maço 3444; O Alabama, 25/5/1865. 
os da Pátria tenham sido recrutados, todos sabiam que eram diferentes dos recrutados para servir como soldado raso no Exército, e os primeiros batalhões de voluntários embarcariam de Salvador no meio de muita pompa e festa em março e abril de 1865.

Doações para o esforço de guerra também afluíram aos cofres provinciais desde fins de 1864, quando o Brasil invadiu o Uruguai, e dispararam quando a notícia da invasão paraguaia de Mato Grosso chegou à província. Funcionários públicos e oficiais militares doaram uma parte de seus salários. Comerciantes e senhores de engenho ofereceram quantias avultadas ao governo. Depois de uma reunião com mais de cem negociantes da praça, em agosto de 1865, o presidente da Bahia relatou que recebera mais de vinte contos para equipar os batalhões da cidade. $\mathrm{O}$ dono de uma imprensa se ofereceu para imprimir gratuitamente as proclamações e circulares relacionadas à guerra, e as estradas de ferro e companhias de navegação não cobravam as passagens dos recrutas e soldados. Sociedades filarmônicas e dramáticas promoveram espetáculos em benefício da mobilização. Os diretores de escolas particulares abriram suas portas aos filhos dos voluntários, sem cobrar-lhes as mensalidades. ${ }^{12}$

As mulheres também participaram da mobilização. Esposas e mães dos militares costuraram camisas e preparam fios de linho para os hos-

12 Sobre essas ofertas, ver "Registro de Donativos", APEB/SACP, maço 3675-1, fols. 86r-146r. A reunião com comerciantes é mencionada pelo Presidente ao Ministro da Guerra, Salvador, 24/8/ 1865, ANRJ/SPE/IG1, maço 125, fols. 276r-77r; e The Anglo-Brazilian Times, 7/9/1865. Muitos outros donativos são mencionados em APEB/SACP, maço 3669; e "Relação dos donativos feitos ao Estado para as despesas da guerra, bem como para aquisição de Voluntários da Pátria ...", 20/4/1866, apêndice ao Brasil, Ministro da Guerra, Relatório (1866). Esses donativos foram analisados por Sílio Bocanera Júnior, “A Bahia na Guerra do Paraguai”, Revista do Instituto Geográfico e Histórico da Bahia, n. 72 (1945), pp. 141-88; Ricardo Salles, Guerra do Paraguai: escravidão e cidadania na formação do Exército, Rio de Janeiro: Paz e Terra, 1990, pp. 98-105; Marcelo Santos Rodrigues, "Os (in)voluntários da Pátria na Guerra do Paraguai (a participação da Bahia no conflito)" (Dissertação de Mestrado, Universidade Federal da Bahia, 2001), pp. 55-6. A mesma história pode ser contada para outras províncias; ver Daví Carneiro, Paraná na Guerra do Paraguai, Rio de Janeiro: Americana, [1940], pp. 119-25; Zildete Inácio de Oliveira Martins, A participação de Goiás na Guerra do Paraguai, Goiâna: UFG Editora, 1983, pp. 70-3; Lucena Filho, "Pernambuco", pp. 89-91; Adauto M. R. da Câmara, O Rio Grande do Norte na Guerra do Paraguai, Natal: Tipografia Galhardo, 1951, pp. 24-7; Maria Regina Santos de Souza, "Impactos da Guerra do Paraguai na província do Ceará (1865-1870)" (Dissertação de Mestrado, Universidade Federal do Ceará, 2007), pp. 71-89. 
pitais de sangue. Mesmo senhoras da alta sociedade pegaram na agulha. Calógeras, sempre crítico, ofereceu "dois dedos de comédia" a seu filho e descreveu a maneira ostentosa com que as "grandes damas" da Corte "entregaram-se ao piedoso trabalho de fazer chumaço para os feridos". Para assegurar a máxima visibilidade, reuniram-se em frente a janelas abertas entre $17 \mathrm{~h}$ e $19 \mathrm{~h} .{ }^{13}$ As senhoras da elite também participaram de uma campanha mais simbólica, lideradas pela viscondessa de Tamandaré (esposa do comandante das forças navais), que convidou as "senhoras brasileiras" a contribuírem com joias para enfeitar uma espada para o imperador. Uma baiana doou "da melhor pulseira que possuo a melhor pedra que ela tinha". ${ }^{14}$ Algumas senhoras se apresentaram para servir de enfermeiras, e Jovita Alves Feitosa, uma jovem do Piauí, teve seu momento de celebridade por ter escondido sua condição feminina e se alistado em um batalhão de voluntários daquela província (no Rio de Janeiro, as autoridades militares negaram-lhe a autorização para seguir para o Sul). ${ }^{15}$

Muitos dos que contribuíram para o esforço de guerra tinham uma conexão com o Estado. Comerciantes e funcionários públicos poderiam ter sofrido reveses nos seus negócios ou nas suas careiras se não tivessem feito doações; viam-nas como serviços que deviam ser compensados. Portanto, como as senhoras da Corte, procuravam dar maior publicidade a seus gestos. O primeiro baiano a se apresentar voluntariamente em 1864, no começo da crise no Uruguai, era major honorário do Exército, tenente-coronel da Guarda Nacional de Salvador e empregado da alfândega. Ele explicitamente pediu que sua oferta fosse submetida ao imperador e se declarou orgulhoso de ser o primeiro baiano a se apresentar "para conter o vandalismo oriental" (isto é, uruguaio, referência ao partido Blanco derrotado pelos brasileiros em 1864-65). ${ }^{16}$

13 J. B. Calógeras a P. G. Calógeras, Rio de Janeiro, 22/1/1865, in Calógeras, Ministério, p. 202.

14 Feliciana Maria de Brito Lopes Alves ao Presidente, Salvador, 31/10/1865, APEB/SACP, maço 3669.

15 June Hahner, Emancipating the Female Sex: The Struggle for Women's Rights in Brazil, 1850-1940, Durham: Duke University Press, 1990, p. 63; Francisco Augusto Pereira da Costa, Cronologia histórica do Estado do Piauí, Rio de Janeiro: Artenova, 1974, v. 2, pp. 501-5.

${ }^{16}$ Gustavo Adolpho de Menezes ao Comandante das Armas, Salvador, 3/5/1864, ANRJ/SPE/ IG1, maço 125, fl. 203. 
Patriotas da classe média, homens respeitáveis, suas aspirações eram pouco diferentes de seus equivalentes na França ou na Prússia, como Morse sugere pensando no patriotismo de uma elite europeizada.

Esse patriotismo contrastava com o que muitos percebiam como preocupante surdez ao apelo da pátria. Da remota vila de Monte Santo, um comandante da Guarda Nacional lamentou que "o povo desta terra não compreende o que é patriotismo, e só marchará se for recrutado", a solução consagrada para conseguir mão de obra militar. ${ }^{17}$ De fato, a primeira reação da maioria dos governos provinciais ao saber da invasão paraguaia foi um novo esforço para recrutar soldados à força. À medida que a notícia da criação dos Voluntários da Pátria chegava às capitais, suspendia-se o temível recrutamento, mas ele não desapareceu completamente em $1865 .{ }^{18} \mathrm{Em}$ fins de 1866 , quando a derrota na batalha de Curupaiti (22 de setembro de 1866) anunciou a necessidade de mais soldados, o recrutamento forçado recomeçaria a todo vapor.

A mistura de voluntariedade e recrutamento forçado criou muita confusão. O comandante das armas da Bahia lamentou a "maneira antimilitar por que procedem os organizadores de forças, levando o paisanismo a tal ponto" de excluí-lo, ele que era "chefe da classe militar nesta província", da indicação de oficiais do Exército (homens sujeitos ao seu comando) para postos nos batalhões de Voluntários da Pátria. Depois da guerra, oficiais deploravam os "cidadãos incompetentes" que tinham sido indicados para o comando de companhias ou batalhões que haviam organizado, o que levou a muitas perdas desnecessárias nos campos de batalha. Tudo isso confirma a observação de Gilberto Freyre de que os brasileiros se ofereceram para defender a pátria "menos como soldados propriamente ditos do que como guerreiros". ${ }^{19}$ Dada a importância das redes de clientelismo no recrutamento,

\footnotetext{
Felisberto José Pinho ao Presidente, Monte Santo, 6/5/1865, APEB/SACP, maço 3669.

18 Para Salvador, essa trajetória pode facilmente ser seguida nos números de janeiro de 1865 d'O Alabama; para outra província, ver Câmara, Rio Grande do Norte, p. 21.

19 Commandante das Armas ao Presidente, Salvador, 19/10/1865, APEB/SACP, maço 3411; José Luiz Rodrigues da Silva, Recordações da campanha do Paraguay, São Paulo: Melhoramentos, 1924, p. 23; Artur Silveira da Mota Jaceguai, Reminiscências da Guerra do Paraguai, Rio de Janeiro: Officina Graphica “A Noite”, 1935, p. 154; Gilberto Freyre, Ordem e progresso, Rio de Janeiro: José Olympio, v. 1, p. 308.
} 
todavia, foi essencial adotar essa maneira de mobilizar o país. Até março de 1866, os 10.189 homens mobilizados pela Bahia haviam embarcado em 37 batalhões ou companhias avulsas, variando em tamanho de doze a 598 homens. ${ }^{20}$ Apenas 593 deles eram recrutas ou voluntários enviados para completar unidades já existentes. De fato, o presidente relutava em mandar recrutas: "É feio", explicou. ${ }^{21}$

Embora as repetidas reorganizações do Exército em Operações apagassem muitas das distinções entre os Voluntários da Pátria e os soldados do Exército, o tema central da mobilização de 1865-66 seria sua feição voluntária. Era, decerto, um mito, pois muitos - talvez a maioria - dos brasileiros que serviram contra o Paraguai estavam nas fileiras contra sua vontade, mas tais mitos foram cruciais para retratar a guerra de uma forma aceitável. ${ }^{22}$ Além disso, o mito tinha uma base na realidade, como demonstra a mobilização de milhares de voluntários em 1865, uma mobilização que tinha raízes profundas na sociedade. O caso dos zuavos, ademais, coloca a questão da origem e da natureza dessa identificação com o Estado e com a nação.

\section{Zuavos e couraças: o legado da guerra pela Independência}

Por que o governo baiano resolveu recrutar companhias de zuavos e couraças em 1865 ainda é um mistério. Recrutar companhias de homens negros negava a bem-estabelecida política militar de não levar em conta a cor dos soldados. As últimas unidades segregadas nas forças armadas brasileiras (os batalhões milicianos de homens pardos e pretos) tinham sido extintas em 1831, quando da criação da Guarda Nacional. O último vestígio da preferência racial no recrutamento, isto é, a exclusão de "homens pretos" das fileiras do Exército, foi abolido em 1837, quando o governo do Regresso sentiu a necessidade de aumentar o seu efetivo. ${ }^{23}$

${ }^{20}$ Bahia, Presidente, Relatório (1866), pp. 16-7.

21 Manoel Pinto de Souza Dantas a Saraiva, Salvador, 24/8/1865, Arquivo do Instituto Histórico e Geográfico Brasileiro, lata 272, pasta 31, doc. 20.

22 Sobre esse ponto, ver também Salles, Guerra do Paraguai: escravidão, p. 61, 63.

23 Sobre essas mudanças na política de recrutamento, ver Hendrik Kraay, Política racial, Estado e forças armadas na época da Independência: Bahia, 1790-1850, São Paulo: Hucitec, 2011, pp. 124-30, 290-91, 311-14, 326-28. 
Desde então, o Exército seria uma instituição formalmente cega à cor da pele, e que levava essa política ao extremo: na fé-de-ofício padrão não tinha lugar para indicar a cor do soldado e, portanto, o Exército não podia fornecer essa informação básica às autoridades policiais encarregadas da captura de desertores. ${ }^{24}$

A proposta para a criação de companhias negras na Bahia veio de fora do Exército, como grande parte da mobilização patriótica de 186566. Quirino Antônio do Espírito Santo (Figura 1) se ofereceu, no dia 26 de janeiro de 1865, para organizar um "respeitável corpo de voluntários" de "cidadãos crioulos", "que pelo seu denodo, coragem e amor à pátria recordar[iam] mais uma vez os valorosos combatentes sob o comando do celebre Henrique Dias". Quirino invocou o patriotismo que tinha sentido durante a guerra pela Independência (1822-23) e proclamou que, "impelido por uma força sobrenatural venho oferecer-me ao governo para ir combater em prol da honra, integridade e soberania do Império, que vis gaúchos pretendem insanamente macular". ${ }^{25}$

A proposta foi logo aprovada e, no dia $1^{\circ}$ de fevereiro, Quirino se instalou no Forte do Barbalho e começou a organizar a companhia. Dentro de poucos dias, tomou o nome de "zuavos baianos" e o presidente aprovou uma subscrição para fardar os novos recrutas com o uniforme garboso das tropas coloniais franceses na Argélia. ${ }^{26}$ Desconheço o porquê da decisão de adotar o nome e o uniforme das tropas coloniais francesas. Na década de 1860, a moda zuava de bombachas vermelhas, colete azul bordado e pequeno boné ou fez já havia sido amplamente divulgada entre diversos exércitos, tais como as forças do Norte e do Sul na guerra civil norte-americana e as tropas internacionais do papa. ${ }^{27}$

${ }^{24}$ Apenas 23,1\% dos 620 avisos sobre desertores, entre 1854 e 1887, tinham informação sobre a cor do soldado, Hendrik Kraay, "O cotidiano dos soldados na guarnição da Bahia (185089)", in Celso Castro, Vitor Izecksohn e Hendrik Kraay (orgs.), Nova História Militar Brasileira, Rio de Janeiro: FGV Editora e Bom Texto, 2004, p. 242.

${ }_{25}$ Quirino Antônio do Espírito Santo ao Presidente, Salvador, 26/1/1865, O Alabama, 6 de fevereiro de 1865 .

26 Sobre a subscrição, ver as cartas da Bahia, 5/2/1865, Jornal do Commercio, 10/2/1865; 14/2/ 1865, Jornal do Commercio, 21/2/1865; Pedro Francelino ao Presidente, Salvador, 6/4/1865, APEB/SACP, maço 3137.

${ }^{27}$ Henri Dutailly, "Les premiers Zouaves (1830-1841)", Revue Historique des Armées, v. 5, n. 4 (1978), pp. 43-52; Lee A. Wallace, “Coppens' Louisiana Zouaves”, Civil War History, v. 8, n. 3 


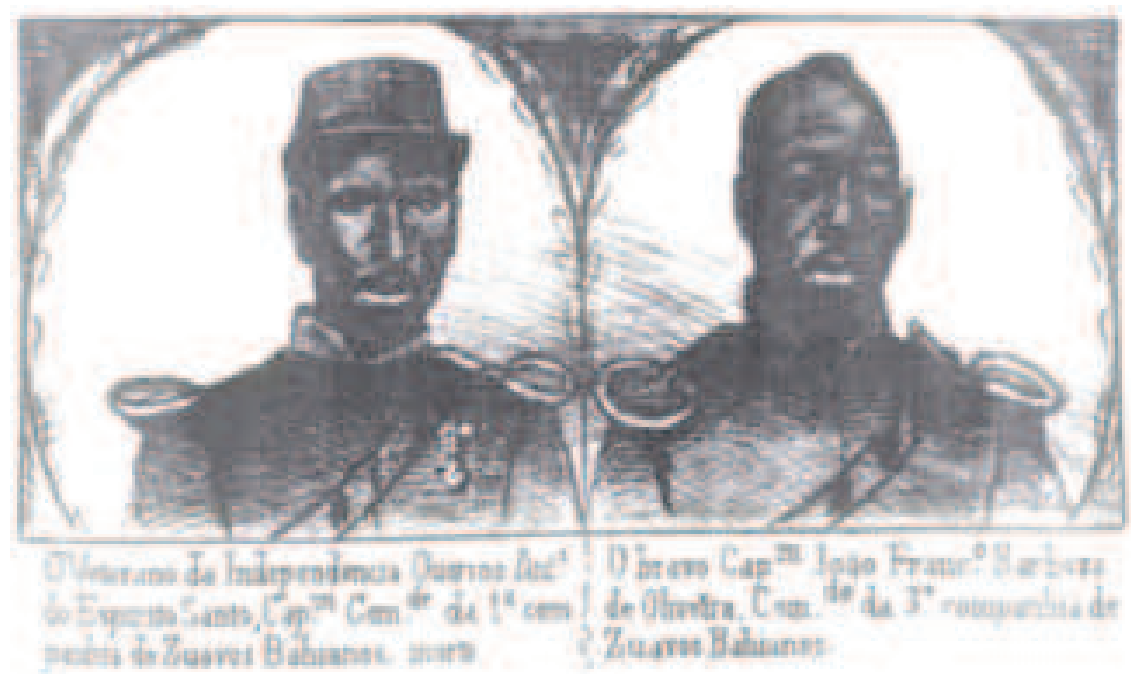

Figura 1: Os Capitães Quirino Antônio do Espírito Santo e João Francisco Barbosa de Oliveira

Fonte: Bahia Illustrada, 7/7/1867.

Marco Antônio Cunha argumenta que a morte heróica de um zuavo francês nascido no Rio de Janeiro durante a tomada da Torre Malakoff na Criméia inspirou a criação dos zuavos baianos uma década depois, mas esse homem - Eduardo de Villeneuve - não foi invocado na mobilização baiana. ${ }^{28}$ Além disso, companhias de zuavos foram criadas apenas na Bahia, e a única outra companhia negra organizada em 1865-66 no Recife adotou o nome somente depois de se reunir aos zuavos baianos no Uruguai. ${ }^{29}$

(1962), pp. 269-92; Gerald E. Wheeler, “D’Epineuil's Zouaves”, Civil War History, v. 2, n. 4 (1956), pp. 93-100; Jean Guenel, La dernière guerre du pape: les Zouaves Pontificaux au secours du Saint-Siège, Rennes: Presses Universitaires de Rennes, 1998.

${ }^{28}$ Cunha, Chama, p. 73. Essa explicação foi proposta pela primeira vez pelo historiador militar do início do século XX, Gustavo Barroso. Ver Paulo de Queiroz Duarte, Os Voluntários da Pátria na Guerra do Paraguai, Rio de Janeiro: Biblioteca do Exército, 1981-89, v. 2, tomo 5, pp. 185-86.

29 Sobre a criação da companhia negra em Pernambuco, ver Lucena Filho, "Pernambuco", pp. 66-7. 
Tabela 1

As Companhias de Zuavos Criadas na Bahia, 1865-66

(por ordem de embarque)

\begin{tabular}{clc}
\hline Número & Comandante & Número de praças \\
\hline 1 & Tenente Quirino Antônio do Espírito Santo & 71 \\
2 & Tenente Marcolino José Dias & 85 \\
3 & Tenente João Francisco Barbosa de Oliveira & 48 \\
4 & Tenente André Fernandes Galiza & 56 \\
5 & Capitão Militão de Jesus Pires & 95 \\
6 & Tenente Francisco Higino Carneiro & 56 \\
7 & Tenente Balbino Nunes Pereira & 12 \\
9 & Alferes Manoel do Nascimento e Almeida & 56 \\
10 & Alferes Eugenio José Moniz & 51 \\
11 & Alferes Nicolau da Silveira & 29 \\
8 & Alferes Nicolau Beraldo Ribeiro de Navarro & 76 \\
Total de Praças & 635 \\
\hline
\end{tabular}

Fonte: Bahia, Presidente, Relatório, 1/3/1866, pp. 16-17.

Onze companhias de zuavos, com um efetivo total de 638 homens, bem como uma companhia de couraças, de 80 homens, embarcaram na Bahia para o Rio de Janeiro e os campos de batalha antes de março de 1866 (há alguns indícios de uma tentativa de criação de uma décima segunda companhia de zuavos, mas é provável que seus integrantes fossem para o Sul na qualidade de recrutas) (Tabela 1$){ }^{30}$ A retórica e as redes pessoais envolvidas na criação dos zuavos baianos lem-

${ }^{30}$ Bahia, Presidente, Relatório (1866), pp. 16-7; "Mappa demonstrativo do pessoal das Companhias de Zuavos, Couraças e Sapadores organizadas pelo Coronel Comandante Superior Joaquim Antonio da Silva Carvalhal", 13/11/1871, APEB/SACP, maço 3675. A única referência à Décima-Segunda Companhia de Zuavos que conheço se encontra na documentação anexa ao requerimento do seu organizador para o melhoramento da sua reforma, resumido em "Projecto n. 67 - 1888: Melhoramento de reforma ao sargento reformado do exército Sotero Joaquim de Almeida", 20/8, ACD (1888), v. 4, pp. 178-79. Em fins de fevereiro de 1866, o sargento Sotero estava preso, acusado de deserção, acusação que ele negava. Suterio [sic] Joaquim de Almeida ao Presidente, Salvador, 23/2/1866, APEB/SACP, maço 3674. 


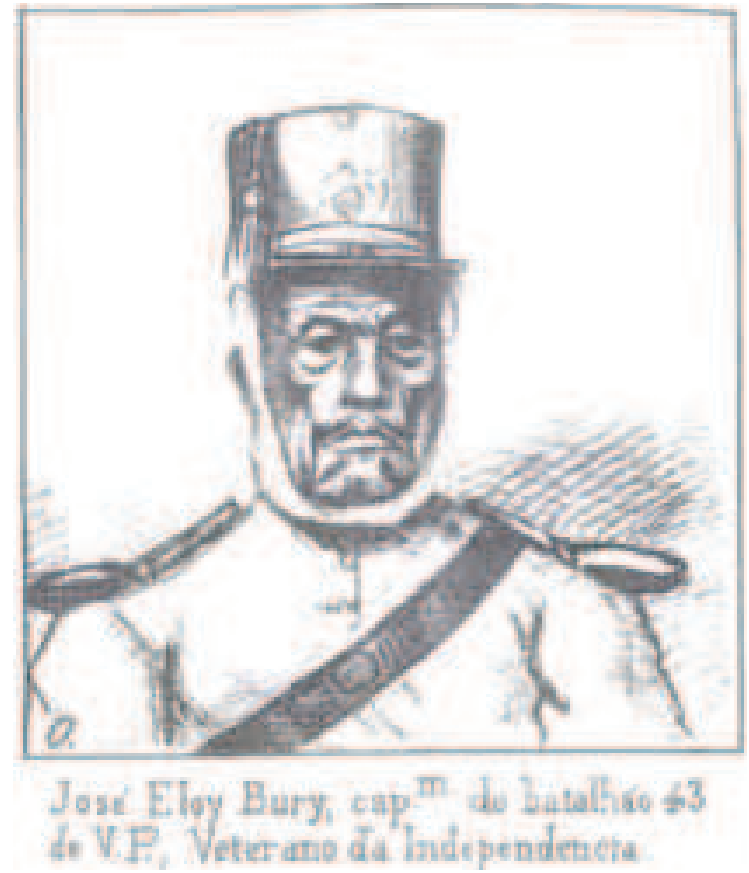

Figura 2: O Capitão José Eloi Buri Fonte: Bahia Illustrada, 11/7/1867.

bravam outras tradições nitidamente brasileiras, algumas das quais elas compartilhavam com a mobilização no resto do país. Como sugere a liderança de Quirino, os veteranos da guerra pela Independência tiveram um papel central na primeira fase da mobilização. A luta contra os portugueses de 1822 a 1823 marcara profundamente a sociedade baiana. ${ }^{31} \mathrm{Na}$ década de 1860 , houve um surto de interesse por essa época heróica. Os veteranos mais jovens já se tornavam sexagenários e, em 1862, fundaram a Sociedade Veteranos da Independência, uma sociedade de assistência mútua que também se encarregava de promover a comemoração dos heróis da Independência ao mandar celebrar missas por suas almas. A Sociedade conquistou um papel importante na comemo-

31 Sobre a Independência na Bahia, ver Kraay, Política racial, cap. 5. Rodrigues também percebeu a importância retórica da Independência na mobilização baiana, “(In)voluntários”, p. 18, $43,51$. 
ração anual do dia Dois de Julho, a data em que as tropas portuguesas evacuaram a cidade do Salvador. ${ }^{32}$ Ela teve um papel importante na mobilização contra o Paraguai; veteranos da Independência formaram guardas de honra para as despedidas das tropas baianas em 1865 e 1866. No final da guerra, a sociedade levantou fundos para as festas da mui esperada vitória. ${ }^{33}$

Muitos dos líderes da primeira fase da mobilização baiana haviam lutado na guerra pela Independência. Quando Quirino embarcou como tenente comandante da Primeira Companhia de Zuavos, seu comandante era o tenente-coronel José da Rocha Galvão, outro veterano da Independência. José Elói Buri, capitão da Companhia de Couraças (Figura 2), também foi veterano das lutas de 1822 e 1823. Os couraças, aliás, lembravam os vaqueiros do sertão, vestidos de couro, que haviam se juntado aos patriotas que sitiavam os portugueses em Salvador. ${ }^{34}$ A essa lista de veteranos da Independência envolvidos na mobilização de 1865, podemos acrescentar o tenente-coronel Domingos Mundim Pestana, comandante do Terceiro Batalhão de Voluntários da Pátria, que havia assentado praça em 1821, com a idade de 15 anos, bem como o coronel Joaquim Antônio da Silva Carvalhal, o principal idealizador da Sociedade Veteranos da Independência e figura chave na organização das companhias de zuavos. ${ }^{35}$ Os comandantes do corpo policial (logo transformado num batalhão de Voluntários da Pátria) e do Batalhão de Caçadores da Bahia também eram veteranos da Independência. ${ }^{36}$

O serviço na luta pela Independência forneceu-lhes contatos que eram úteis. Durante a sua curta escala no Rio de Janeiro em demanda ao Sul, Rocha Galvão e Quirino receberam uma visita de Antônio Pereira Rebouças, o estadista mulato que havia liderado a defesa de Cachoeira

32 "Estatutos da Sociedade Veteranos da Independencia", APEB/SACP, maço 3802.

33 O Alabama, 24/1/1865; Carta da Bahia, 1/4/1868, Jornal do Commercio, 10/4/1868; O Alabama, 21/3/1868.

34 Sobre a criação dos couraças, ver O Alabama, 3/8/1865, 12/8/1865 e 4/11/1865.

35 Requerimento de Domingos Mundim Pestana ao Imperador, Salvador, 21/1/1841, AHEx/RQ, D-26-709; fé de ofício de Joaquim Antônio da Silva Carvalhal, AHEx/RQ, JJ-119-3115.

36 Respetivamente, Joaquim Maurício Ferreira e José Baltazar da Silveira; sobre a atuação desses homens na luta pela Independência, ver Jornal do Commercio, 7/1/1865; e Kraay, Politica racial, p. 185, 258. 
contra os portugueses em 1822, juntamente com Rocha Galvão e seus irmãos. ${ }^{37}$ Poucos dos veteranos idosos resistiram aos rigores da campanha. Quirino faleceu em novembro no hospital de Montevidéu, e Pestana, doente e cego, já estava de volta a Salvador em fevereiro de 1866; morreu dois anos mais tarde. Outros resistiram por mais tempo. Rocha Galvão foi morto durante a primeira batalha de Tuiuti (24 de maio de 1866), e Buri sucumbiu ao cólera três dias antes de sua licença médica ter sido anunciada, em fins de $1867 .{ }^{38}$ Enquanto podiam servir, todavia, suas idades lhes garantiram o respeito de seus soldados, a julgar por uma descrição da Primeira Companhia de Zuavos durante uma curta escala em Desterro (hoje Florianópolis): Quirino foi descrito como "um velho preto [que] parece um verdadeiro homem de bem, a quem os seus soldados respeitam-no como a um pai". 39

A liderança das companhias de zuavos e couraças não só remontava à época da Independência, mas também lembrava uma tradição mais antiga, a da milícia negra abolida em 1831. Na sua proposta, Quirino invocou Henrique Dias, o homem negro que liderara uma tropa de negros livres nas lutas seiscentistas contra os holandeses em Pernambuco. Depois dessa guerra, sua tropa foi transformada numa unidade de milícia. Tais regimentos, denominados Henriques em homenagem ao seu primeiro comandante, proliferaram no século XVIII e formavam um elo chave entre homens de cor e o Estado colonial. Seu oficialato chegou a constituir uma elite negra. Na Bahia, os Henriques distinguiramse na luta pela Independência, mas os reformadores liberais da década de 1820 solaparam seu status nas forças armadas do novo país independente. Quando da criação da Guarda Nacional, em 1831, o governo aboliu a milícia de homens pretos e pardos. Oficiais e soldados milicianos

\footnotetext{
37 André Pinto Rebouças, Diário e notas autobiográficas: texto escolhido e anotações, organizado por Ana Flora e Inácio José Veríssimo, Rio de Janeiro: José Olympio, 1938, p. 65.

38 Sobre a morte de Quirino, ver o requerimento da sua viúva, Sabina Joanna do Espirito Santo, ao Presidente, Salvador, ca. 1866, APEB/SACP, maço 3670. A volta de Pestana e a sua morte foram noticiadas por $O$ Alabama, 1/3/1866 e 7/5/1868. A morte de Rocha Galvão é mencionada por $O$ Alabama, 14/6/1866; a licença e a morte de Buri foram anunciadas em ODs 163 e 164, Tuyu-cuê, 6/12/1867 e 7/12/1867, Exército em operações na Republica do Paraguay sob o commando em chefe de todas as forças, de S. Ex. Sr. Marechal do Exercito Luiz Alves de Lima e Silva, Duque de Caxias, Rio de Janeiro: Typ. de Francisco Alves de Souza, 1877, v. 2, p. 449, 455.

39 Citado em Duarte, Voluntários, v. 2, tomo 5, p. 189.
} 
descontentes apoiaram a Sabinada (1837-38), cujo governo rebelde restaurou seu status, mas muitos dos seus líderes foram mortos no massacre dos derrotados no final da revolta. ${ }^{40}$

Em Pernambuco oitocentista, o patriotismo provincial, que via a expulsão dos holandeses no século XVII como o momento fundador da identidade pernambucana, mantinha viva a memória dos Henriques. ${ }^{41}$ $\mathrm{Na}$ Bahia, ao contrário, os Henriques estavam completamente ausentes do discurso baiano entre 1838 e 1864 . Todavia, a criação das companhias de zuavos inspirou uma onda de retórica patriótica que lembrava os heróis negros da luta pela Independência, uma invocação do que Francis Albert Cotta qualifica como o "mito de Henrique Dias". ${ }^{42} \mathrm{Na}$ sua despedida da Segunda Companhia de Zuavos, Carvalhal conclamouos a combater "denodados contra os paraguaios como o intrépido e imortal Henrique Dias combateu outrora os holandeses e na gloriosa época da Independência o denodado tenente-coronel Manoel Gonçalves [da Silva], fazendo sobressair o valor e [a] bravura da vossa cor" ${ }^{43}$ Para o embarque da Primeira Companhia de Zuavos, Francisco Moniz Barreto, então o poeta baiano mais popular (e também um veterano da Independência), escreveu às pressas o "Hino dos zuavos baianos", cuja primeira estrofe e o estribilho são bem representativos da retórica patriótica de 1865:

Sou crioulo: da guerra na crisma

Por zuavo o meu nome troquei

Tenho sede de sangue inimigo

Por bebê-lo o meu sangue darei

${ }^{40}$ Essa discussão resume a análise da milícia negra em Kraay, Política racial, passim; é mais concisamente apresentada em Hendrik Kraay, "Identidade racial na política, Bahia, 17901840: o caso dos Henriques”, in István Jancsó (org.), Brasil: formação do Estado e da nação, São Paulo: HUCITEC, Ed. UNIJUÍ, FAPESP, 2003, pp. 521-46.

${ }^{41}$ Evaldo Cabral de Mello, Rubro veio: o imaginário da restauração pernambucana, 2. ${ }^{\mathrm{a}}$ ed., Rio de Janeiro: Topbooks, 1997, pp. 34, 50, 53-54, 195-96, 220-24; Lucena Filho, "Pernambuco", pp. 66-7.

42 Francis Albert Cotta, Negros e mestiços nas milícias da América portuguesa, Belo Horizonte: Crisálida, 2010, p. 26.

43 "Despedida do organisador da 2. ${ }^{a}$ Comp. ${ }^{a}$ de Zuavos Bahianos, Joaquim Antonio da Silva Carvalhal", 1/5/1865, BNRJ/SM, II-34, 5, 47. Essa palestra foi também reproduzida em "Em-

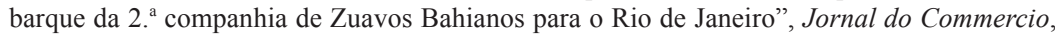
$10 / 5 / 1865$. 
D'Henrique Dias

Neto esforçado

Voo ao teu brado

Pátria gentil!

Mais que o da França

Ligeiro e bravo

Seja o zuavo

Cá do Brasil

As outras estrofes lembravam o serviço de Gonçalves na guerra pela Independência e avisavam aos paraguaios e aos Blancos uruguaios que temessem a ira dos zuavos. ${ }^{44}$

Essa retórica não era apenas simbólica, pois havia conexões diretas entre os zuavos de 1865 e os Henriques da década de 1820. Por algumas semanas em fevereiro e março de 1865, o capitão Joaquim José de Santana Gomes foi encarregado da organização da Segunda Companhia de Zuavos; até 1831, ele havia sido ajudante do batalhão dos Henriques. ${ }^{45}$ Entre os que embarcaram na Primeira Companhia de Zuavos havia o primeiro cadete Constantino Luiz Xavier Bigode, filho do último comandante do batalhão negro (morto no massacre pós-Sabinada). ${ }^{46}$ Embora não existissem livros de registro do batalhão dos Henrique para confirmálo, é de supor que alguns dos oficiais zuavos haviam servido nas fileiras do batalhão negro na década de 1820. Da mesma forma, o organizador e comandante da companhia negra pernambucana, Felipe José da Exaltação Maniva, tinha assentado praça na milícia negra daquela província em 1817 e fora promovido a alferes em $1821 .^{47}$

Pouco se sabe das ocupações civis dos oficiais zuavos. Segundo o conde d'Eu, que visitou o exército no Rio Grande do Sul em 1865, muitos haviam sido sargentos na Guarda Nacional, o que sugere que

44 "Hymno dos Zuavo Bahianos", O Alabama, 1/3/1865. No início do século XX, Manoel Raimundo Querino registrou uma versão um pouco diferente, A Bahia de outrora, Salvador: Progresso, 1955, pp. 185-86.

${ }^{45}$ Cartas da Bahia, 27/2/1865 e 24/3/1865, Jornal do Commercio, 7/3/1865 e 6/4/1865. Sobre Gomes, ver Kraay, Politica racial, pp. 162, 325, 338-46.

46 Manoel Querino, "Os homens de côr preta na história", Revista do Instituto Geográfico e Histórico da Bahia, v. 48 (1923), p. 363.

47 Requerimento de Felippe Jose da Exaltação Maniva ao Imperador, Rio de Janeiro, 7/6/1874, AHEx/RQ, F-18-672. 
gozavam de pelo menos uma modesta posição social e econômica. Tanto Buri como o tenente da Companhia de Couraças João Capistrano Fernandes haviam sido oficiais na Guarda antes de 1850. Na época, exigia-se uma renda anual mínima de 400 mil-réis para servir de oficial nessa força, e metade dela para servir como simples guarda. ${ }^{48}$ Encontrei apenas três referências às ocupações civis dos oficiais negros: Maniva era carpinteiro, Bigode marceneiro e Capistrano administrador de uma tipografia. O capitão André Fernandes Galiza possuía uma roça nos arredores de Salvador. ${ }^{49} \mathrm{O}$ sargento organizador $12^{\mathrm{a}}$ Companhia de Zuavos alegou ter gasto "alguma fortuna que havia herdado de seus pais, como o produto da venda, que se viu obrigado a fazer, de um estabelecimento comercial que possuía", na sua tentativa frustrada de criá1a. ${ }^{50}$ Essa evidência sugere que muitos dos oficiais zuavos e couraças vinham da classe dos artesãos qualificados, um perfil bastante similar ao dos oficiais Henriques antes de $1831 .{ }^{51}$ Também indica que os oficiais zuavos tinham origens sociais mais baixas do que os funcionários públicos e os profissionais que se apresentaram voluntariamente em 1865 e que dominavam a oficialidade dos Voluntários da Pátria.

A retórica da mobilização dos zuavos, bem como a experiência de indivíduos chaves que participaram da sua mobilização, sugere que as companhias racialmente segregadas incorporavam uma viva tradição de serviço patriótico por parte de homens negros. Os veteranos idosos da época da Independência lideraram uma boa parte da mobilização inicial em 1865 e se viam como sucessores dos heróis negros das lutas passadas contra invasores estrangeiros. Que esses homens tivessem corrido às armas em 1865 não deve surpreender, pois eles, ou seus pais, tinham feito o mesmo quatro décadas antes. Os mais jovens certamente haviam sido criados com histórias dos heróis militares negros das guerras passadas.

${ }^{48}$ Conde d'Eu, Viagem militar ao Rio Grande do Sul, São Paulo: Companhia Editora Nacional, 1936, p. 135; Carvalhal ao Presidente, Salvador, 13/9/1865, APEB/SACP, maço 3454. Sobre a qualificação para servir na Guarda, ver Kraay, Política racial, pp. 327-28.

49 Requerimento de Maniva ao Imperador, 5/9/1837, AHEx/RQ, F-18-672; Requerimento de Constantino Luiz Xavier Bigode ao Ministro do Império, Salvador, 12/6/1875, AHEx/RQ, C60-1707; O Alabama, 23/9/1865 e 19/11/1868.

50 "Projecto n. 67 - 1888", $A C D$ (1888), v. 4, p. 178.

51 Kraay, Politica racial, p. 144. 


\section{$O$ recrutamento para as companhias negras: cor, política e clientelismo}

Muito menos se sabe sobre os soldados dos zuavos do que sobre seus oficiais. As poucas fontes sugerem que essas companhias incluíam uma mistura de voluntários e de homens recrutados à força, semelhante ao perfil geral da mobilização brasileira de 1865. O capitão Quirino declarou orgulhoso que apenas "voluntários espontâneos" serviam na Primeira Companhia de Zuavos, mas essa declaração foi motivada pela recusa de um desses "voluntários" a jurar bandeira. ${ }^{52} \mathrm{O}$ caso clássico de apresentação de voluntários veio de fora de Salvador: Cândido da Fonseca Galvão (o futuro Dom Obá II), filho de um africano liberto, levou trinta voluntários de Lençóis a Salvador, onde logo assentaram praça na Terceira Companhia de Zuavos, com Galvão promovido a alferes na véspera do embarque. ${ }^{53}$

Os que apresentavam voluntários, como Galvão, ganhavam muito prestígio. Muito depois da guerra, um sargento lembrou que em 1865 circulavam editais "em que o governo prometia conferir o posto de capitão ou de tenente comandante a quem organizasse companhias de voluntários de 20 homens". ${ }^{54}$ Não encontrei nenhum desses editais, e é pouco provável que o governo tivesse divulgado uma fórmula tão matematicamente rígida para a promoção de organizadores dos voluntários, mas a lembrança do sargento capta bem a importância de recompensar os que haviam se esforçado para a mobilização. André Fernandes Galiza reclamou da dificuldade em organizar uma companhia de zuavos enquanto João Francisco Barbosa de Oliveira (Figura 1) estava encarregado da organização de outra. Barbosa teve mais sucesso que Galiza e embarcou como tenente comandante da Terceira Companhia de Zuavos, com 48 homens (mas a maioria deles eram os voluntários de Lençóis trazidos por Candido Galvão). A Quarta Companhia de Zuavos, do te-

52 Quirino ao Comandante das Armas, Salvador, 24/2/1865, APEB/SACP, maço 6463.

53 Silva, Dom Obá II, pp. 41-3, 47-8. O número de voluntários mobilizados por Galvão é alegado no seu "Memorial" ao imperador, Salvador, 27 de março de 1872, AHEx/RQ, C-17-539. Não conheço nenhum outro documento comprobatório, mas a promoção de Galvão a alferes é um forte indício de que ele realmente mobilizou um grupo de voluntários.

54 “Projecto n. 67 - 1888", $A C D$ (1888), v. 4, p. 178. 
nente Galiza, que em fins de julho tinha apenas sete soldados e dois sargentos, além do próprio organizador, embarcou em agosto, segundo o comandante das armas, com apenas doze homens (e um estoque completo de oitenta uniformes). ${ }^{55}$ No ano seguinte, o presidente relatou que essa companhia havia embarcado com 56 homens, e atribuiu a cifra de doze homens à Sétima Companhia, o que é evidentemente um engano (ver Tabela 1).

Como já vimos, apresentar-se como voluntário raramente foi uma decisão individual, e os voluntários normalmente apresentavam-se em grupos, com frequência sob a liderança de um patrão. O papel de indivíduos proeminentes na organização das companhias de zuavos e couraças, entre eles Carvalhal e também Abílio Cesar Borges, o educador e futuro barão de Macaúbas, é outro indício de clientelismo (Borges adquiriu oitenta espingardas para a Quinta Companhia da Zuavos, cuja organização ele supervisionou). ${ }^{56}$ Outros recrutas aparentemente sucumbiram à pressão de "amigos": em novembro, um zuavo voluntário se arrependeu da sua decisão de assentar praça, alegando ter sido "iludido por amigos que se banquetearam em certa ocasião". ${ }^{57}$

Assentar praça numa companhia de zuavos tinha significado social específico, pois implicava servir numa companhia negra. É de supor que os "voluntários espontâneos" de Quirino compartilhassem uma identidade racial que os levasse à companhia negra em vez de aos outros batalhões que estavam sendo organizados na mesma época. Alguns guardas nacionais recrutados solicitaram que fossem mandados para uma companhia de zuavos em agosto de 1865, o que talvez indique semelhante identidade racial. As autoridades militares e policiais aparentemente se esforçavam para manter o perfil racial dos zuavos. $\mathrm{O}$ comandante das armas selecionava os recrutas crioulos das levas do interior para mandá-los aos zuavos, e excluiu um homem de uma das

55 Requerimento de Andre Fernandes Galliza ao Presidente, ca. junho de 1865, APEB/SACP, maço 3438; Comandante das Armas ao Presidente, Salvador, 26/7/1865, APEB/SACP, maço 3448; 21/8/1865, APEB/SACP, maço 3454.

${ }^{56}$ Carta da Bahia, 13/9/1865, Jornal do Commercio, 22/9/1865; Abílio Cesar Borges ao Presidente, Salvador, 21/12/1865, APEB/SACP, maço 3669.

57 Comandante das Armas ao Presidente, Salvador, 2/11/1865, APEB/SACP, maço 3424. 
companhias zuavas "por ser de cor parda". ${ }^{58}$ A polícia também colaborou nesse sentido e assegurou que os dezesseis crioulos encontrados entre 464 recrutas fossem levados às companhias de zuavos no final de $1865 .{ }^{59}$

Há indícios de um surto de recrutamento forçado para as companhias de zuavos em meados de 1865. Em agosto, O Alabama recomendou que o governo desse baixa a certo Veríssimo, que sofria de doença mental e provocou desordens com seus gritos quando tentou fugir do quartel para evitar o serviço militar. No mesmo mês, esse jornal relatou que as companhias de zuavos então sendo organizadas tinham listas de guardas nacionais a serem designados para suas fileiras. $\mathrm{O}$ chefe de polícia enviou outro guarda aos zuavos na qualidade de recruta depois de prendê-lo numa casa de jogos. No dia 26 de agosto, soldados zuavos tentaram recrutar a força um escravo pardo, Simão, que conseguiu escapar mergulhando no mar, mas morreu afogado. ${ }^{60}$

Dois outros casos de recrutamento de escravos sugerem certa solidariedade entre zuavos e escravos, que aparentemente apresentaram-se voluntariamente. Um escravo jovem, João, foi mandado à rua para comprar folhas de banana; duas horas mais tarde, estava fardado de zuavo e pronto para servir a seu país, e não mais a seu dono, que logo solicitou a devolução da sua propriedade. Quando o dono de outro escravo, João Gualberto da Silva, reclamou a sua devolução, foi insultado pelos zuavos; no dia seguinte, ele descobriu que seu escravo já havia assentado praça, o que implicava um processo mais complicado para conseguir sua baixa do serviço militar. Ademais, João Gualberto era um liberto sob condição, o que enfraquecia o direito de propriedade do seu dono, e o presidente ordenou que este apresentasse mais documentos comprobatórios do seu direito de posse. Um mês mais tarde, João

58 Comandante das Armas ao Presidente, Salvador, 10/8/1865, APEB/SACP, maço 3438; 26/7/ 1865, APEB/SACP, maço 3448; 24/10/1865, APEB/SACP, maço 3411.

59 Osvaldo Silva Felix Júnior, "Repensando a Guerra (a participação da Bahia na Guerra do Paraguai), 1865-1870” (Dissertação de Mestrado, Universidade Estadual da Bahia, 2009), pp. 63-7.

${ }^{60}$ O Alabama, 1/8/1865, 22/8/1865 e 31/8/1865; João Francisco Barbosa de Oliveira ao Comandante das Armas, Salvador, 5/6/1865, APEB/SACP, maço 3444; Comandante das Armas ao Chefe de Polícia, 11/9/1865, APEB/SACP, maço 6463; O Alabama, 11/9/1865. 
Gualberto ainda estava na prisão militar, preso enquanto durassem as averiguações sobre sua condição. ${ }^{61}$ Nesses dois casos, é provável que os escravos fossem cúmplices no seu recrutamento e que os zuavos os tivessem ajudado a fugir do cativeiro. Depois dessa conjuntura, não houve mais reclamações sobre o recrutamento forçado para as companhias de zuavos, o que sugere que tinham sido devidas aos excessos de um determinado oficial.

Algumas outras fontes sugerem que os soldados zuavos eram, às vezes, desordeiros e que estavam bem integrados à cultura popular e à vida das ruas. O Alabama reclamou, no início de junho de 1865 , que as guardas da companhia de zuavos "leva[va]m a noite a provocar desordens, a bulir com as negras e a atirar foguetes e roletes [de cana] em cima de quem passava". "Uma porção de moleques", meninos negros, portanto, se juntava aos divertimentos dos zuavos e por isso ganharam o apelido de "zuavinhos". ${ }^{62}$ Haviam começado a festejar o São João bem antes do seu dia, 24 de junho.

O papel da política partidária na mobilização de 1865-66 tem sido pouco estudado, embora a política moldasse o recrutamento tanto em tempo de guerra como em tempo de paz. ${ }^{63}$ Os governos progressistas, compostos de liberais e conservadores moderados, detinham o poder entre 1862 e 1868, e tanto os saquaremas (conservadores) como os liberais históricos não cansavam de denunciar o que consideravam os excessos dos situacionistas. O correspondente conservador baiano do Jornal do Commercio (do Rio de Janeiro), por exemplo, condenou a indicação de Marcolino José Dias para comandar a Segunda Compa-

${ }^{61}$ Esses dois casos podem ser seguidos nos documentos seguintes: Requerimento de Florencio da Silva e Oliveira ao Presidente, ca. 1865, APEB/SACP, maço 3696; O Alabama, 2/9/1865, 4/9/1865 e 4/10/1865; Comandante das Armas Interino ao Presidente, Salvador, 9/9/1865, APEB/SACP, maço 3432. Dois escravos tiveram mais sucesso em escapar de seus donos através das companhias de Zuavos, pois seus donos souberam do seu paradeiro após eles terem embarcado com, respectivamente, a Primeira e a Segunda Companhia de Zuavos. Ver Felix Júnior, "Repensando", pp. 84-5. Sobre os tramites para reclamação de escravos foragidos encontrados no Exército, ver Hendrik Kraay, “'O abrigo da farda': o Exército brasileiro e os escravos fugidos, 1800-1888", Afro Ásia, v. 17 (1996), pp. 29-56.

${ }^{62}$ O Alabama, 6/6/1865. Nesse sentido, os zuavos pouco diferiam dos outros soldados brasileiros, Kraay, Política racial, caps. 3 e 7; Beattie, Tribute, cap. 7; Kraay, "Cotidiano", pp. 237-68.

63 Hendrik Kraay, "Repensando o recrutamento militar no Brasil imperial", Diálogos, v. 3, n. 3 (1999), pp. 113-51. 


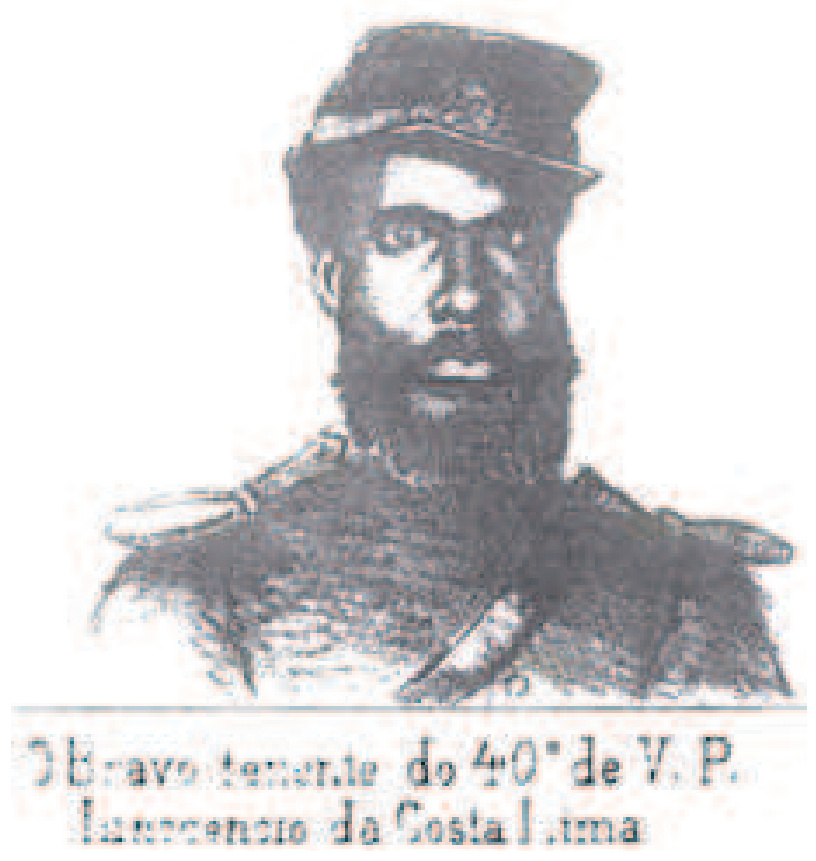

Figura 3: O Tenente Inocêncio da Costa Lima Fonte: Bahia Illustrada, 1/9/1867.

nhia de Zuavos, pois o novo tenente era um liberto que "nada tem feito para nobilitá-lo". O jornalista alegou que Marcolino vivia de ser espião da polícia baiana e que havia sido promovido a sargento na Guarda Nacional "por causa do terror que durante a eleição infundiam as suas cabeçadas a todo mundo". Durante uma recente sessão da assembleia provincial, Marcolino liderava uma "porção de capangas" que se reunia na galeria para intimidar o único deputado oposicionista. ${ }^{64}$

A referência às cabeçadas de Marcolino é um indício da ligação entre a política partidária e o mundo da rua, dominado pelos negros, entre eles capoeiras. Embora as maltas de capoeiras fossem características da vida no Rio de Janeiro oitocentista, há poucas referências à

${ }^{64}$ Cartas da Bahia, 26/3/1865 e 10/4/1865, Jornal do Commercio, 6/4/1865 e 15/4/1865. 
capoeira em Salvador. Na Corte, os capoeiras enfrentavam a repressão policial, mas também se incorporavam às redes clientelísticas dos partidos políticos, como havia feito o tenente Marcolino. ${ }^{65}$ Manoel Raimundo Querino, o cronista da história afro-baiana, escreveu, no início do século XX, que o governo baiano havia mandado muitos capoeiras aos campos de batalha no Paraguai, onde se distinguiram nos combates, como a tomada de Curuzu em setembro de $1866 .{ }^{66}$ Embora não haja referências específicas ao recrutamento de capoeiras baianos durante a guerra, Marcolino efetivamente se distinguiu nessa batalha.

As acusações contra Marcolino, cuja veracidade não importa, demonstram a sua inserção na política partidária. Outros o viam com bons olhos. De volta a Salvador em 1867, era uma figura popular: "Aonde vai é acompanhado por uma multidão de povo", relatou $O$ Alabama.${ }^{67} \mathrm{~A}$ queda do gabinete de Zacarias de Góis e Vasconcelos e a ascensão dos saquaremas ao poder em julho de 1868 complicou a vida do então capitão Marcolino. Por pouco escapou de uma tentativa de assassinato em setembro. O correspondente do Jornal do Commercio duvidava que a polícia se esforçasse para identificar o culpado, pois a pretendida vítima era um "liberal e um dos que tem tomado aqui mais ativa parte em eleições pelo seu partido. Há muito juraram os dominadores [da província] dar-lhe uma lição de mestre". ${ }^{6}$

Enquanto estavam fora do poder, os saquaremas podiam apenas reclamar do que consideravam indicações de homens não qualificados. Os progressistas asseguraram que os zuavos tivessem um perfil de destaque: durante os festejos do Dois de Julho de 1865, os zuavos, garbosamente vestidos, guardaram o palanque onde se realizavam as principais comemorações públicas. ${ }^{69} \mathrm{O}$ periódico liberal Bahia Ilustrada abriu

${ }^{65}$ Thomas H. Holloway, “'A Healthy Terror': Police Repression of Capoeira in NineteenthCentury Rio de Janeiro", Hispanic American Historical Review, v. 69, n. 4 (1989), pp. $637-$ 76; Carlos Eugênio Líbano Soares, A capoeira escrava e outras tradições rebeldes no Rio de Janeiro (1808-1850), Campinas: Editora da Unicamp, 2001; Carlos Eugênio Líbano Soares, A negregada instituição: os capoeiras na Corte imperial, 1850-1890, Rio de Janeiro: Access, 1999.

${ }^{66}$ Querino, Bahia, pp. 78-80.

${ }^{67}$ O Alabama, 22/6/1867.

${ }^{68}$ Carta da Bahia, 29/9/1869, Jornal do Commercio, 15/10/1869.

69 Carta da Bahia, 5/7/1865, Jornal do Commercio, 11/7/1865. 
suas primeiras páginas aos oficiais zuavos e couraças, e publicou os retratos de quatro deles, entre os de outros patriotas homenageados em 1867-68 (Figuras 1, 2 e 3). As companhias de zuavos foram sempre incluídas nas comemorações das primeiras vitórias das armas brasileiras, entre elas a tomada de Montevidéu e a Batalha do Riachuelo. ${ }^{70}$

A figura chave na organização das companhias de zuavos foi o coronel Joaquim Antônio da Silva Carvalhal, que integrava muitas das redes já analisadas. Era comandante superior reformado da Guarda Nacional e empregado aposentado da alfândega, onde havia trabalhado por muitos anos. Lutou como cadete na guerra pela Independência. ${ }^{71}$ Gozava de muito prestígio entre os que foram recrutados para as companhias de zuavos, de cujo treinamento ele estava encarregado. Ajudou os parentes dos zuavos. Cedeu uma das suas casas à família do sargento Inocêncio da Costa Lima (Figura 3), e depois do falecimento deste, a Bahia Ilustrada relatou que Carvalhal pretendia doar a casa à viúva. Era tutor do filho de Marcolino e, em 1869, cuidou do funeral do filho do capitão Barbosa. Marcolino e Inocêncio agradeceram-lhe publicamente a ajuda. ${ }^{72}$ Carvalhal apresentou a proposta de criação da Companhia de Couraças ao presidente da província. Foi padrinho de casamento de um voluntário couraça na véspera do embarque, e depois ajudou a mulher a requerer a consignação do salário do soldado que ela não havia recebido por mais de um ano. A Bahia Ilustrada relatou que ele pessoalmente agenciara o alistamento de muitos outros soldados. ${ }^{73}$

Não se sabe de onde veio a influência de Carvalhal entre os oficiais e soldados negros das companhias de zuavos e couraças, mas muitos deles haviam servido sob suas ordens na Guarda Nacional. Era um militante

${ }^{0}$ O Alabama, 11/3/1865 e 14/9/1865.

71 Testamento de Carvalhal, 17/6/1878, APEB/SJ, Livros de Registro de Testamentos, v. 55, fols. $10 \mathrm{v}-11 \mathrm{r}$.

${ }^{72}$ Carvalhal ao Presidente, Salvador, 14/3/1865, APEB/SACP, maço 3454; requerimento de Carvalhal ao Presidente, [Salvador], ca. 1866, APEB/SACP, maço 3671; "Registro de donativos", APEB/SACP, maço 3675-1, fols. 93v-94r; Bahia Illustrada, 1/12/1867; O Alabama, 17/7/1869; "Despedida", O Alabama, 4/5/1865; "Despedidas", Jornal do Commercio, 10/5/1865.

73 Carvalhal ao Presidente, Salvador, 31/7/1865, APEB/SACP, maço 3454; Requerimento de Silvana Porcina de S. José ao Presidente, Salvador, 18/9/1866 (com documentos anexos), APEB/SACP, maço 3674; "O Coronel Joaquim Antonio da Silva Carvalhal”, Bahia Illustrada, $5 / 5 / 1867$. 
do Partido Liberal, e $O$ Alabama o propôs como o "candidato popular" nas eleições municipais de 1868 , nas quais os saquaremas, que controlavam a máquina eleitoral, obtiveram uma vitória esmagadora. ${ }^{74}$ As ligações entre Carvalhal e Marcolino destacam essa conexão liberal. Ademais, como um líder na Sociedade Veteranos da Independência, Carvalhal tinha conexões com muitos veteranos comandantes dos batalhões baianos. Também era ligado a associações afro-baianas. Em 1859, serviu como "sócio protetor" da Sociedade Protetora dos Desvalidos, uma instituição de assistência mútua (alguns outros homens envolvidos na organização das companhias de zuavos também haviam servido na mesa da SPD). ${ }^{75}$ Uma década depois, era um dos fundadores da Sociedade Humanitária Abolicionista, que se reunia na sua espaçosa casa. Em 1870, Carvalhal fez uma conexão direta entre os zuavos e o movimento abolicionista quando libertou uma criança sua escrava no dia 7 de setembro. Quem teve a honra de entregar a carta de alforria foi o capitão Barbosa. ${ }^{76}$

Carvalhal também tinha seu quinhão de inimigos. Sua independência da hierarquia militar irritava o comandante das armas. Já em janeiro de 1865 foi censurado por se corresponder diretamente com o presidente da província, em vez de enviar seus ofícios através da hierarquia militar. ${ }^{77}$ Em 1866, depois do embarque da última companhia de zuavos, Carvalhal se ofereceu para criar companhias ou mesmo um batalhão "de africanos e crioulos, libertos", acrescentando que queria fazêlo como encarregado pelo presidente, sem sujeição ao comandante das armas, que talvez lhe fizesse "advertências inca[bí]veis". O presidente negou-lhe a autorização, mas, no início de 1867, Carvalhal organizou as companhias de sapadores, compostas principalmente dos escravos libertos pelos donos depois de receberem indenização do governo. $\mathrm{O}$ comandante das armas reclamou que Carvalhal atuava fora da sua alça-

74 O Alabama, $17 / 7 / 1868$ e 5/9/1868.

75 P. de S., Memorias da viagem de Suas Magestades Imperiaes á provincia da Bahia, Rio de Janeiro: Typographia Industria Nacional de Cotrim \& Campos, 1867, pp. 112-13; Júlio de Santana Braga, Sociedade Protetora dos Desvalidos: uma irmandade de cor, Salvador: Ianamá, 1987, p. 73.

76 O Alabama, $18 / 9 / 1869$ e 7/9/1870.

77 O Alabama, 18/1/1865. 
da quando fazia promoções, reconhecia cadetes e autorizava licenças, tudo sem consultá-lo. Dessa forma, os novos sapadores tiveram uma formação "mais própria para viciá-los do que para os tornar bons soldados". ${ }^{78}$ Surpreendentemente, a essa altura as redes que convergiam para Carvalhal ainda podiam gerir voluntários. Francisco Antônio de Carvalhal Menezes e Vasconcelos, um ex-cadete demitido por "mau comportamento" em 1856, que voltou ao serviço militar na qualidade de sargento da Primeira Companhia de Sapadores (e talvez um parente de Carvalhal), apresentou 21 voluntários à companhia. ${ }^{79}$

Apesar da capacidade de Carvalhal de organizar companhias e encontrar voluntários, o presidente recusou-se a encarregá-lo do recrutamento provincial em fins de 1867, para o qual Carvalhal havia se oferecido a servir gratuitamente. Durante um mês, a Bahia Ilustrada condenou a decisão. Nos seus editoriais, o periódico louvou Carvalhal e acusou o homem indicado para a tarefa de covardia e de incompetência. Outros jornais se juntaram em vão ao clamor em favor de Carvalhal. ${ }^{80}$

A organização das companhias de sapadores no início de 1867, bem como a indicação de Felipe José da Exaltação Maniva para organizar uma companhia "Henrique Dias" no Recife, em meados desse ano, foram as últimas tentativas de recrutar companhias racialmente segregadas para a Guerra do Paraguai. ${ }^{81}$ A essa altura, o Império precisava, não de mais companhias avulsas, mas de recrutas para os batalhões existentes.

${ }^{78}$ Requerimento de Carvalhal ao Presidente, ca. 1866, APEB/SACP, maço 3671; O Alabama, 11/9/1866 e 11/12/1866; Comandante das Armas ao Presidente, Salvador, 23/2/1867, APEB/ SACP, maço 3414. A composição social das companhias de sapadores pode ser inferida do Comandante das Armas ao Chefe de Polícia, Salvador, 10/2/1867, APEB/SACP, maço 6464. Sobre o recrutamento de escravos, ver Hendrik Kraay, "Escravidão, cidadania e recrutamento militar na Guerra do Paraguai”, Estudos Afro-Asiáticos, v. 33 (1998), pp. 17-51.

79 Requerimentos de Francisco Antônio de Carvalhal Menezes e Vasconcelos (e documentos anexos, entre eles, uma lista desses voluntários), AHEx/RQ, F-48-1617. A capacidade de Vasconcelos de incentivar voluntários não fez dele um bom oficial inferior, e ele foi demitido em janeiro de 1869 "por incorrigível", OD 2, Assunção, 29/1/1869, Exercito em Operações na Republica do Paraguay sob o commando em chefe interino de S. Ex. o Sr. Marechal de Campo Guilherme Xavier de Souza, Rio de Janeiro: Typ. de Francisco Alves de Souza, 1877, p. 12.

${ }^{80}$ Bahia Illustrada, 3/11/1867, 10/11/1867 e 1/12/1867; O Alabama, 2/11/1867; cartas da Bahia, 4/11/1867 e 24/11/1867, Jornal do Commercio, 12/11/1867 e 2/12/1867.

81 Comandante das Armas ao Presidente, Recife, 29/7/1867, Arquivo Público do Estado de Pernambuco, CA 81, fl. 207. É provável que Maniva não conseguisse organizar essa companhia, pois nunca alegou esse serviço depois da guerra, AHEx/RQ, F-18-672. 
Cada vez mais desesperado, o governo recrutava a força, designava guardas nacionais e recorria à "compra" de escravos, que eram libertos e logo alistados. A essa altura, também, as companhias de zuavos já não existiam no Exército em Operações na República do Paraguai.

\section{Os zuavos na guerra}

Não é fácil seguir as companhias de zuavos depois do seu embarque na capital baiana e muito do que se tem escrito recentemente sobre a atuação desses soldados na guerra é cheio de lacunas e equívocos. A história institucional dos zuavos apresentada pelo historiador militar Paulo de Queiroz Duarte é em geral confiável, mas ele só trata das quatro primeiras companhias, e não menciona as outras sete que embarcaram em fins de 1865 e no início de $1866 .{ }^{82}$ Eduardo Silva, o biógrafo de Dom Obá, erra ao identificar o 24æ\% Batalhão de Voluntários da Pátria (designação dada ao Terceiro Batalhão baiano pelo governo imperial) como um batalhão de zuavos, e também erra ao supor que a Terceira Companhia de Zuavos (na qual Dom Obá serviu de alferes) estava anexa a esse batalhão durante a campanha. ${ }^{83} \mathrm{O}$ que a documentação jornalística, os requerimentos e as ordens do dia revelam é uma história bem mais complicada - e muito mais interessante -, que demonstra a ambivalência dos comandantes militares para com as companhias negras, bem como o orgulho pelo serviço militar por parte dos oficiais zuavos, muitos dos quais efetivamente se distinguiram na guerra.

As companhias de zuavos, anexas aos batalhões de Voluntários de Pátria, saíram de Salvador, uma por uma, e geralmente faziam escala no Rio de Janeiro a caminho do Sul. $\mathrm{Na}$ Corte, às vezes, houve algumas mudanças nas companhias: na Segunda Companhia, o tenente Marcolino José Dias, por exemplo, foi promovido a capitão, e o alferes Firmino José das Dores passou a tenente. ${ }^{84}$ A Primeira Companhia de Zuavos despertou muita curiosidade na capital, a julgar pela charge publicada

82 Duarte, Voluntários, v. 2, tomo 5, pp. 184-204.

83 Silva, Dom Obá II, pp. 45-54. Esse equívoco é repetido por Ricardo Salles, Guerra do Paraguai: memórias e imagens, Rio de Janeiro: Edições Biblioteca Nacional, 2003, p. 38, 45.

84 "Gazetilha", Jornal do Commercio, 22/5/1865. 


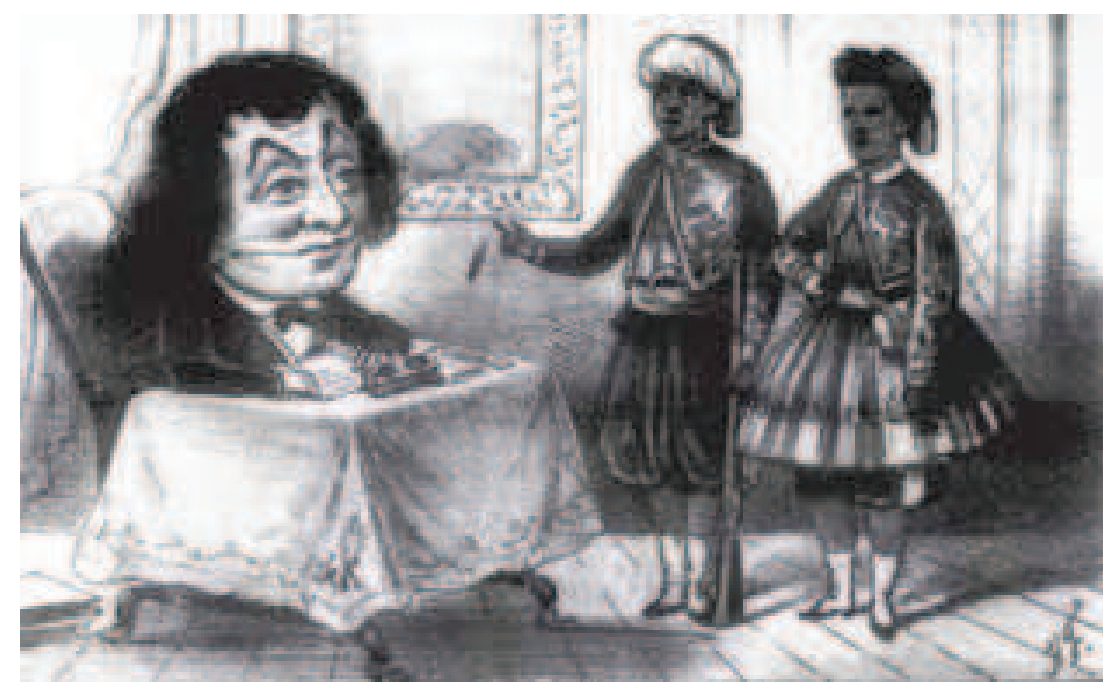

Figura 4: Os zuavos no Rio de Janeiro

Fonte: Semana Illustrada, 2/4/1865.

na Semana Ilustrada que sugeria que os homens de cor fluminenses pretendiam emular o patriotismo baiano (Figura 4). Um autoidentificado "crioulo da Corte" conclamou seus companheiros a exceder os baianos e a criar um batalhão de zuavos. ${ }^{85}$ Durante uma curta escala em Desterro, Santa Catarina, a Primeira Companhia de Zuavos destacou-se por sua "robustez e disciplina" ${ }^{86}$ A certa altura, a Primeira e a Segunda Companhias de Zuavos foram reunidas e mandadas rio acima de Montevidéu. Tiveram seu batismo de fogo nos combates na frota improvisada encarregada de cortar a comunicação entre as duas colunas paraguaias que avançavam nas margens do rio Uruguai. Depois que a vitória aliada na Batalha de Yataí (17 de agosto) pôs fim à coluna inimiga na margem direita do rio, as duas companhias foram mandadas a Uruguaiana, aonde chegaram a tempo de presenciar a rendição paraguaia no dia 18 de setembro. Ali o Conde d'Eu julgou-as "a mais linda tropa [...] de todo o

85 O Crioulo da Corte, "Zuavos", Correio Mercantil, 23/3/1865.

${ }^{86}$ Citado por Duarte, Voluntários, v. 2, tomo 5, p. 189. 
Exército". Ele teve uma impressão muito favorável dos oficiais, que eram atentos ao serviço e "orgulhosos do seu batalhão [sic]" ${ }^{87}$

Durante os meses seguintes, a Primeira e a Segunda Companhias de Zuavos continuavam anexas à Marinha; o capitão Quirino adoeceu e faleceu no hospital de Montevidéu. Antes de dezembro, os zuavos voltaram ao Exército e no dia $1^{\circ}$ de dezembro de 1865, no acampamento de São Borja, o barão de Porto Alegre (Manoel Marques de Souza) organizou um Corpo Provisório de Zuavos para integrar o Segundo Corpo do Exército. Desse corpo provisório faziam parte a Primeira, Segunda e Terceira Companhias de Zuavos da Bahia, bem como a companhia negra pernambucana comandada por Maniva que, até então, não havia tomado o nome de zuavos (é provável que soldados e oficiais da pequena Quarta Companhia de Zuavos tenham se juntado a esse corpo provisório, pois seu comandante, André Fernandes Galiza, estava lá em janeiro). O capitão Marcolino foi indicado como comandante interino do Corpo Provisório de Zuavos, mas ele foi demitido no dia $1^{\circ}$ de janeiro de 1866 e um capitão do Exército, promovido a major em comissão, foi indicado para comandar os zuavos. ${ }^{88}$

A morte do respeitado Quirino e a reorganização das companhias de zuavos provocaram, segundo Francisco Otaviano, o plenipotenciário brasileiro, "alguma perturbação no batalhão [sic] dos zuavos e de São Borja recebo queixas constantes". ${ }^{89}$ Não se sabe exatamente o que aconteceu, mas no dia 12 de janeiro de 1866, Porto Alegre anunciou a demissão do alferes Candido da Fonseca Galvão, "por mau comportamento habitual e desordeiro", e a exoneração, "por haverem requerido", do capitão Maniva e do tenente Galiza. ${ }^{90}$ Não se sabe se a exoneração dos dois era uma manifestação de solidariedade com Galvão. O

87 Duarte, Voluntários, v. 2, tomo 5, p. 190; Thomas L. Whigham, The Paraguayan War, Lincoln: University of Nebraska Press, 2002, p. 346; Augusto Tasso Fragoso, História da guerra entre a Tríplice Aliança e o Paraguai, Rio de Janeiro: Imprensa do Estado Maior do Exército, 1956, v. 2, p. 225 (nota 115) e 269; Conde d'Eu, Viagem, p. 135.

${ }_{88}$ Duarte, Voluntários, v. 2, tomo 5, pp. 189-95.

${ }^{89}$ Otaviano a Ângelo Muniz da Silva Ferraz, Buenos Aires, 7/2/1866 (reservado), in Otaviano, Cartas, pp. 150-51.

90 OD 54, São Borja, 13/1/1866, Exercito em Operações na Republica do Paraguay, Segundo Corpo sob o comando em chefe do Exm. Sr. Tenente General Manoel Marques de Souza, Conde de Porto Alegre, Rio de Janeiro: Typ. de Francisco Alves de Souza, 1877, v. 2, pp. 30-1. 
futuro Dom Obá procurou Otaviano em Buenos Aires e explicou ao diplomata que havia sido inocentado por dois conselhos de guerra. Otaviano, portanto, julgou a exoneração uma injustiça e explicou que "o pobre homem me apareceu corrido de vergonha"; o diplomata não tinha poder para reverter uma ordem do general, mas recomendou que o ministro de guerra transferisse o alferes a outro corpo. ${ }^{91}$ Isso não aconteceu, e no início de março o governo imperial dispensou-o do serviço do Exército "por seu mau estado de saúde". ${ }^{92}$ Apesar dessas dificuldades, o Corpo Provisório de Zuavos ficou com o Segundo Corpo do Exército, sob o comando de Porto Alegre. Numa reorganização do Segundo Corpo, no dia $1^{\circ}$ de maio de 1866 , os zuavos passaram a integrar a Primeira Brigada da Primeira Divisão. ${ }^{93}$

Um segundo contingente de zuavos, composto das últimas companhias organizadas na Bahia, aos poucos se formava no Primeiro Corpo do Exército, sob o comando de Manoel Luiz Osório (o futuro Marquês de Herval). Na véspera da invasão do Paraguai em abril de 1866, ele os transferiu ao serviço de saúde e os soldados zuavos foram mandados para trabalhar nos hospitais. O Alabama lamentou que esses homens, "dignos de melhor sorte, est[avam] reduzidos a faxineiros nos hospitais e outros misteres de igual jaez". ${ }^{94}$ Como os outros comandantes brasileiros, Osório não precisava de pequenas unidades avulsas numa época em que era mister manter o estado completo dos batalhões. ${ }^{95}$ Assim que chegou ao seu acampamento em Laguna Brava, em janeiro, ele dissolveu a Companhia de Couraças e transferiu seus oficiais e soldados a outros corpos. ${ }^{96}$

91 Otaviano para Ferraz, Buenos Aires, 7/2/1866 (reservado), in Otaviano, Cartas, p. 151.

${ }^{2}$ OD 79, São Thomaz, 15/5/1866, Exercito em Operações ... M. M. Souza, v. 2, p. 224.

93 OD 78, São Thomaz, 1/5/1866, Exército em Operações ... M. M. Souza, v. 2, p. 208.

94 Duarte, Voluntários, v. 2, tomo 5, pp. 195-94; "Correspondencia encyclopedica de Alabama", Tuyutí, 2/8/1866, O Alabama, 4/9/1866. A designação desses Zuavos para servir nos hospitais foi mencionada por dois contemporâneos, Cerqueira, Reminiscências, 104; André Rebouças, Diário: A Guerra do Paraguai (1866), organização de Maria Odila Silva Dias, São Paulo: Instituto de Estudos Brasileiros, 1973, p. 71, 113.

95 Cunha, Chama, pp. 76-7.

96 Duarte, Voluntários, v. 2, tomo 5, pp. 197-98, 203-4; OD 127, Lagoa Brava, 10/2/1866, Exército em Operações na Republica do Paraguay, Primeiro Corpo, sob o comando em chefe do Exm. General Manoel Luiz Osorio, Marques de Herval, Rio de Janeiro: Typ. de Francisco Alves de Souza, 1877, v. 2, p. 125. 
Esse foi provavelmente o destino das últimas companhias de zuavos organizadas na Bahia, que embarcaram no início de 1866. Transformar os soldados zuavos em faxineiros e enfermeiros, todavia, cheira à atitude escravocrata sobre o papel adequado para homens negros. Nem todos concordaram. Depois da guerra, Dionísio Cerqueira lamentou que Osório não houvesse aproveitado a tradição guerreira de Henrique Dias exemplificada pelos zuavos. ${ }^{97}$

Entretanto, o Corpo Provisório de Zuavos ainda fazia parte do Segundo Corpo do Exército em Corrientes; esse corpo finalmente entrou em território inimigo no dia $1^{\circ}$ de setembro de 1866 para atacar as fortificações ribeirinhas paraguaias, numa operação apoiada pela Marinha. No dia 25 de agosto, Porto Alegre ordenara a dissolução do Corpo Provisório de Zuavos e a distribuição do seu pessoal entre outras unidades (é possível que esse corpo tivesse recebido reforços de algumas das últimas companhias de zuavos vindas da Bahia durante o inverno). Ao que parece, não houve tempo para executar a ordem de dissolução antes da Batalha de Curuzu ( 3 de setembro), na qual os baianos e os pernambucanos lideraram o ataque contra as trincheiras e fortificações inimigas. O pernambucano de 66 anos, capitão Felipe José da Exaltação Maniva, foi "um dos primeiros a transpor as referidas trincheiras debaixo de um mortífero fogo". O capitão capoeira Marcolino subiu a muralha inimiga por sobre as costas de um de seus soldados, retirou uma bandeira paraguaia, hasteou o pavilhão verde-amarelo no seu lugar e, segundo Manoel Querino, anunciou: "Está aqui o negro zuavo baiano!" A coragem de Marcolino foi louvada em ordens do dia, registrada na imprensa do Rio de Janeiro e de Salvador, e posteriormente lembrada por folcloristas, entre eles Querino. ${ }^{98}$ Candido López, o artista que chegou a Curuzu com os reforços argentinos alguns dias depois da batalha,

\footnotetext{
Cerqueira, Reminiscências, p. 104.

98 Sobre a atuação de Maniva, ver Atestado, Antonio Martins d'Amorim Rangel, Rio de Janeiro, 7/7/1873, AHEx/RQ, F-18-672 (citação). Sobre Marcolino, ver Querino, "Homens", p. 362 (citação); OD 87, Curuzu, 14/9/1866, Exército em Operações ... M. M. Souza, v. 2, p. 327, 335, 336; O Alabama, 29/9/1866; Rozendo Moniz, "À victoria do Curuzu", 20/9/1866, Jornal do Commercio, 6/10/1866; João Varella, Da Bahia que eu vi, Salvador: Tipografia do Povo, 1935, p. 16.
} 
recordou a presença dos zuavos com seus "uniformes garbosos", e os incluiu no seu quadro do acampamento, pintado em 1891. 99

No final de setembro ou no início de outubro de 1866, o Corpo Provisório de Zuavos foi definitivamente dissolvido, além de muitas outras unidades, como parte da reorganização constante do Exército por causa das perdas maciças por doenças e na Batalha de Curupaiti (22 de setembro), na qual quatro oficiais zuavos foram feridos (um faleceu depois); mais três foram louvados por atos de bravura nessa batalha. ${ }^{100}$ No dia 30 de outubro, nove capitães, tenentes e alferes das extintas companhias de zuavos foram oficialmente transferidos para oito batalhões diferentes de Voluntários da Pátria, ordem que indica uma política de separá-los. ${ }^{101}$ As fardas distintivas registradas pelo pintor argentino cederam ao uniforme normal e, de fato, não há nenhum retrato contemporâneo dos zuavos no traje peculiar de $1865 .{ }^{102}$

A carreira militar dos oficiais zuavos, agora melhor qualificados de ex-zuavos, pode ser seguida durante o resto da guerra. Muitos ingressaram as longas listas de baixas que se acumulavam nas trincheiras em frente da fortaleza de Humaitá e nos insalubres acampamentos aliados. Além de José Elói Buri, o tenente Manoel Teodoro de Jesus faleceu de cólera. Um "ferimento de estilhaço de bomba" foi a causa da morte do tenente Augusto Francisco da Silva em março de 1867, e mais dois oficiais dos ex-zuavos morreram de ferimentos ou de doenças não

99 "Vista de interior de Curuzú mirado de aguas arriba (norte a sur) el 20 de setiembre de 1866", 1891, Museu Nacional de Bellas Artes (Buenos Aires), reproduzida em Marta Gil Solá e Marta Dujovne, Cándido López, Buenos Aires: Associación Amigos del Museo Nacional de Bellas Artes de Buenos Aires, 1971, pp. 25-6. Essa imagem é também reproduzida em Salles, Guerra do Paraguai: memórias, pp. 44-5.

${ }^{100}$ OD 88, Curuzu, 10/10/1866, Exercito em Operações ... M. M. Souza, v. 2, p. 486 (tenente Manoel Nascimento de Almeida, morto); v. 2, p. 487 (capitão Militão de Jesus Pires, ferido), v. 2, p. 488 (tenente Nicolau Beraldo Ribeiro Navarro, contuso); v. 2, p. 508 (alferes Innocencio da Costa Lima, ferido). Para os elogios, ver Exercito em Operações ... M. M. Souza, v. 2, p. 425 (capitão Barbosa); v. 2, p. 439 (alferes Nicolau da Silveira); e procuração, Nicolau Beraldo Ribeiro de Navarro, Curupayty, 9/12/1868, BN/SM, Documentos Biográficos, C.988.38.

${ }^{101}$ OD 89, Curuzu, 30/10/1866, Exército em Operações ... M. M. Souza, v. 2, p. 545.

${ }^{102}$ As fotos existentes de Cândido da Fonseca Galvão e de Marcolino José Dias, todas da época pós-guerra, retratam-nos no uniforme militar convencional, George Ermakoff, O negro na fotografia brasileira do século XIX, Rio de Janeiro: G. Ermakoff Casa Editorial, 2004, p. 82; Varella, Da Bahia, p. 13; Pedro e Bia Corrêa do Lago, Coleção Princesa Isabel: fotografia do século XIX, Rio de Janeiro: Capivara, 2008, p. 158. 
especificadas nos meses seguintes. ${ }^{103}$ Outros, como os capitães Marcolino e Maniva, deram baixa por incapacidade física não especificada, entre eles também o alferes Bernardino de Sena Trindade e o tenente Balbino Nunes Pereira. ${ }^{104}$ Poucos serviram por toda a guerra. O capitão João Francisco Barbosa de Oliveira, comandante da Terceira Companhia de Zuavos, fez toda a campanha, mas não foi promovido (de fato, nenhum ex-zuavo chegou a major; capitão foi a graduação mais alta alcançada por eles). Ferido duas vezes, Barbosa nunca pediu licença, como explicou com orgulho num requerimento pós-guerra; ele estava entre as tropas que mataram Francisco Solano López em Aquidabã. ${ }^{105} \mathrm{O}$ cadete Constantino Luiz Xavier Bigode foi capturado pelos paraguaios pouco depois da Batalha de Curupaiti e passou mais de dois anos como prisioneiro de guerra, trabalhando na fundição de Ybicuí. Liberado em 1869, ele voltou ao serviço e foi promovido a alferes em março de $1870 .{ }^{106}$

José Soares Cupim Júnior teve menos sorte que Barbosa e Bigode. Um dos primeiros voluntários zuavos (assentou praça na Primeira Companhia no dia $1^{\circ}$ de fevereiro de 1865 ), ele embarcou como sargento, e durante a guerra aos poucos foi promovido até chegar a capitão. Louvado por atos de bravura na Batalha de Curuzu, foi ferido na segunda Batalha de Tuiuti (24 de setembro 1867). Restabeleceu-se e voltou ao serviço, mas foi ferido no primeiro dia das lutas em Lomas Valentinas (21 de dezembro de 1868). Não resistiu e faleceu no dia 13 de janeiro de 1869, pouco depois da ocupação aliada de Assunção. Em 1871, sua viúva, dona Panfília Luiza Tolentino Soares, passou a receber uma pensão anual de 720 mil-réis. ${ }^{107}$ Aliás, o parlamento aprovou pensões às

${ }^{103}$ OD 255, Surubi-hy, 26/7/1868, Exército em Operações ... Caxias, v. 4, p. 234; OD 96, 15/3/ 1867, Exército em Operações ... M. M. Souza, v. 2, p. 611; ODs 70 e 72, Tuyuty, 29/4/1867 e 7/5/1867, Exército em Operações ... Caxias, v. 1, p. 388, 401 (o alferes Nicolau Tolentino Alberto Pituba e o capitão Firmino José das Dores).

${ }^{104}$ ODs 10 e 82, Tuyuty, 7/12/1866 e 2/6/1867, Exército em Operações ... Caxias, v. 1, p. 48, 475.

${ }^{105}$ Requerimento de Barbosa ao Imperador, Rio de Janeiro, 27/9/1873, AHEx/RQ, JZ-8-2233. Querino erra ao escrever que Barbosa faleceu no Paraguay, "Homens", p. 363.

${ }^{106}$ OD 44, Villa do Rosario, 14/3/1870, Exercito em Operações na Republica do Paraguay sob o comando em chefe ... Conde d'Eu, Rio de Janeiro: Typ. de Francisco Alves de Souza, 1877, p. 783; Querino, "Homens", p. 363.

${ }^{107}$ A fé de ofício de Cupim foi resumida para o debate do Senado sobre a pensão para sua viúva, 8/7/ 1871, Anais do Senado (1871), v. 3, pp. 46-7. Sua coragem e seus ferimentos foram mencionados 
viúvas de mais quatro oficiais zuavos falecidos: Sabina Joana do Espírito Santo (viúva de Quirino), Francisca Maria da Conceição (viúva de Tolentino), Josefina das Trevas Lima (viúva de Inocêncio) e Arcanja de São Miguel Silva Serra (viúva de Augusto Francisco da Silva). ${ }^{108}$

Não se sabe quase nada da experiência militar dos soldados rasos das companhias de zuavos, mas é de supor que não diferia muito da dos seus oficiais. Como a maioria destes, lutaram, sofreram e morreram no anonimato. Alguns tiveram baixas por motivo de saúde, "tuberculose pulmonar incurável", no caso do soldado Quirino José dos Santos. ${ }^{109}$ Homens qualificados de soldados da "companhia" ou do "corpo de zuavos da Bahia" aparecem nas longas listas de veteranos incapazes que recebiam pensões em $1867 .{ }^{110}$

\section{Conclusão}

Em 1870, três batalhões de Voluntários da Pátria voltaram à Bahia. Foram recebidos com muita festa e logo depois dissolvidos. Muitos soldados deram baixa sem receber os soldos atrasados que o governo ainda lhes devia. ${ }^{111}$ Poucos oficiais ou soldados das companhias de zuavos estavam entre os veteranos que voltaram naquele ano. Carvalhal preparou uma coroa de louros para receber o capitão Barbosa, o único oficial zuavo mencionado pela imprensa baiana na sua cobertura das festas. Em versos dedicados a Carvalhal, um poeta saudoso lamentou o falecimento dos "nossos velhos amigos", Rocha Galvão, Buri e Quirino, os veteranos da Independência que haviam servido como exemplo à juventude baiana, e logo passaram a bandeira à nova geração. ${ }^{112}$

Sem dúvida, os ex-zuavos acharam difícil a volta à vida civil,

em OD 87, Curuzu, 14/9/1866, Exercito em Operações ... M. M. Souza, v. 2, p. 316; OD 135, Tuyu-Cuê, 9/10/1867, Exercito em Operações ... Caxias, v. 2, p. 229; OD 7, Luque, 3/5/ 1869, Exercito em Operações ... Conde d'Eu, p. 114.

${ }^{108} A C D(1867)$, v. 2 , p. $60 ; A C D$ (1869), v. 1 , p. $72 ; A C D$ (1869), v. 1 , p. $82 ; A C D$ (1870), v. 1 , p. 97.

${ }^{109}$ OD 57, São Borja, 25/1/1866, Exercito em Operações ... M. M. Souza, v. 2, p. 49. Para outro exemplo, ver OD 85, Itapirú, 3/8/1866, Exercito em Operações ... M. M. Souza, v. 2, p. 297.

110 "Pensões a diversos", $A C D$ (1867), v. 2, p. 188, 203, 372, 374; v. 3, p. 415.

111 O Alabama, 28/5/1870 e 1/6/1870.

${ }^{112}$ O Alabama, 29/3/1870 e 31/7/1870. 
como os demais veteranos. Bigode, recompensado com a patente de alferes honorário do Exército, que não lhe dava direito a soldo, solicitou uma pensão em 1875 alegando que era incapaz de sustentar sua família por causa de ferimentos recebidos na guerra. $\mathrm{O}$ requerimento foi indeferido. ${ }^{113}$ Como Bigode, Marcolino ficou em Salvador. Segundo um cronista posterior, ele foi reduzido a trabalhar como varredor de rua até receber um emprego como porteiro da biblioteca pública. Até a sua morte, em 1888, o capitão Marcolino era muito conhecido em Salvador. Costumava liderar patriotas durante as festas do dia 2 de julho. Fez parte do movimento abolicionista e também serviu na mesa da Sociedade Protetora dos Desvalidos em 1886. ${ }^{114}$

Outros se juntaram a Cândido da Fonseca Galvão na emigração baiana para o Rio de Janeiro, analisada por Eduardo Silva. Como Galvão, Maniva e Barbosa passaram tempo no Asilo dos Inválidos da Pátria na Corte; seus requerimentos no Arquivo Histórico do Exército demonstram que não cansavam de solicitar promoções, pensões e condecorações ao imperador e ao ministro da guerra, destacando o patriotismo com que serviram, no Paraguai como voluntários, à pátria.

Infelizmente, nenhum desses homens deixou documentos que possam revelar sua visão política de forma tão extensa como fez o alferes Candido da Fonseca Galvão, melhor conhecido na década de 1880 no Rio de Janeiro como Dom Obá II, numa longa série de artigos nos jornais fluminenses. Como a maioria dos veteranos, eles se reintegraram à população livre e pobre de cor da qual tinham sido recrutados. Em Salvador a memória dos zuavos perdurou. No início do século XX, Manoel Querino registrou seus nomes e seus feitos militares a partir de tradições orais. ${ }^{115} \mathrm{~A}$ essa altura, todavia, não havia lugar para soldados negros no imaginário público de um regime republicano cujo ideal era uma sociedade europeizada. Mesmo o Império oferecera pouco aos seus defensores negros, como Silva deixa claro na sua biografia de Galvão/

${ }^{113}$ Requerimento de Bigode ao Ministro do Império, Salvador, 12/6/1875 (e documentos comprobatórios), AHEx/RQ, C-60-1707.

${ }^{114}$ Varella, Da Bahia, pp. 13, 14-5; Jailton Lima Brito, A Abolição na Bahia, 1870-1888, Salvador: CEB, 2003, p. 66, 76, 266; Braga, Sociedade, p. 75.

${ }^{115}$ Querino, "Homens". 
Obá. O imperador Dom Pedro II recebia o "Príncipe do Povo" no palácio, mas pouco depois da Abolição, o ato mais popular do governo imperial, o monarca seria deposto. ${ }^{116}$

É possível que os soldados negros tivessem voltado "com novo espírito, com capacidade mais ampla de analisar a sociedade escravista brasileira", como sugere Nelson Werneck Sodré, ${ }^{117}$ mas o Império (e menos ainda a República) ofereceu-lhes poucos meios para se integrarem à nação pela qual lutaram. Como Miguel Angel Centeno observou para América Latina, "um sentimento de nacionalidade ativo e ardente demais", como aquele manifestado pelos zuavos em 1865, "podia criar condições ameaçadoras à dominação pela elite". ${ }^{118} \mathrm{O}$ Brasil precisava de tais patriotas em 1865, mas depois da guerra, a estreita cultura política do país oferecia pouco espaço para homens como os zuavos apresentarem suas reivindicações, e muito menos para exercerem a plena cidadania.

\section{Post-scriptum: o problema da fé de ofício de Dom Obá II}

O leitor atento já terá percebido que a história da participação de Cândido da Fonseca Galvão na Guerra do Paraguai não corresponde à que o folclorista Alexandre José de Melo Morais Filho registrou sobre ele no final do século XIX, isto é, que os seus companheiros na Corte diziam que "a sua fé de ofício [era] limpa e elogiosa". Essa avaliação foi repetida por muitos folcloristas e cronistas posteriores. ${ }^{119}$ A demissão dele "por mau comportamento habitual e desordeiro" em janeiro de 1866

\footnotetext{
${ }^{116}$ Silva, Dom Obá II, cap. 7.

${ }^{117}$ Nelson Werneck Sodré, A história militar do Brasil, Rio de Janeiro: Civilização Brasileira, 1979, p. 143.

${ }^{118}$ Miguel Angel Centeno, Blood and Debt: War and the Nation-State in Latin America, University Park: Pennsylvania State University Press, 2002, p. 31.

${ }^{119}$ Alexandre José de Mello Moraes Filho, Festas e tradições populares do Brasil, Rio de Janeiro: F. Briguiet, 1946, p. 543; [Francisco] Ferreira da Rosa, "Memorial de [sic] Rio de Janeiro: personagens - fatos - narrativa de acontecimentos - vida e progresso da cidade em meio século (1878-1928)", Arquivo do Distrito Federal, v. 2 (1951), p. 53; R[aimundo] Magalhães Junior, O Império em chinelos, Rio de Janeiro: Civilização Brasileira, 1957, p. 260; Roberto Macedo, "Efemerides cariocas", Revista do Instituto Histórico e Geográfico Brasileiro, v. 315 (1977), p. 44. Essa contradição também foi percebida por Felix Junior, "Repensando", pp. $93,174-75$.
} 
não era, todavia, desconhecida. Logo depois da sua manifestação monarquista no dia 2 de dezembro de 1889, o governo provisório da República cassou o decreto que the concedera as honras do posto de alferes, citando a demissão. ${ }^{120}$

A história do decreto cassado é curiosa. Uma vez demitido em 1866, Galvão não tinha mais direito a ser tratado de alferes, pois, como todos os oficiais dos Voluntários da Pátria, não tinha patente de oficial do Exército. Durante a guerra, o governo geralmente concedia honras do posto aos oficiais voluntários logo depois da sua demissão por motivos de saúde. Pelo menos oito dos oficiais zuavos receberam essas patentes honorárias do Exército durante ou logo depois da guerra, entre eles os capitães Maniva e Marcolino, ambos em junho de 1867, "por serviços relevantes prestados na guerra atual" ${ }^{121}$ Através da concessão dessas honras, eles recebiam o direito de usar a farda e de serem tratados como oficiais. Eram apenas honras, pois a concessão delas não dava direito à pensão. ${ }^{122} \mathrm{O}$ orgulho da farda é bem patente nas fotografias existentes do capitão Marcolino (e do alferes Galvão). ${ }^{123} \mathrm{Em}$ 1870, com já vimos, logo depois da conclusão da guerra, o capitão Barbosa e o alferes Bigode obtiveram as honras dos seus respectivos postos.

Galvão não as recebeu em 1866 e, na qualidade de "ex-alferes", ele solicitou-as através de um requerimento ao imperador datado de 31 de março de 1871. Nele, não alegou ter feito a campanha e apenas mencionou que uma "moléstia" não especificada "o impossibilitou de prosseguir". Isso foi confirmado pela secretaria do comando das armas da Bahia, que localizou a ordem do dia na qual foi anunciada a sua "dispensa do posto de comissão, que tinha no Exército, por seu mau estado de saúde", no dia 5 de março de $1866 .{ }^{124}$ Instado a apresentar sua fé de

${ }^{120}$ Decreto, 6/12/1889, publicado em “D. Obá II”, Diario do Commercio, 7/12/1889.

${ }^{121}$ OD 116, Tuyu-cuê, 13/8/1867, Exercito em operações ... Caxias, v. 2, pp. 97-8.

${ }^{122}$ Sobre o status legal do oficial honorário, ver Manoel Joaquim do Nascimento e Silva, Synopsis de legislação militar brasileira até 1874 cujo conhecimento mais interessa aos empregados do Ministério da Guerra, Rio de Janeiro: Typ. do Diario do Rio de Janeiro, 1874, q.v. oficial honorário.

${ }^{123}$ Ermakoff, Negro, p. 82; Varella, Da Bahia, p. 13; Lago e Lago, Coleção Princesa Isabel, p. 158.

${ }^{124}$ Requerimento de Candido da Fonseca Galvão ao Imperador, Salvador, 31/3/1871; e atestado, Secretaria do Comando das Armas, Salvador, 6/5/1871, AHEx/RQ, C-17-539. 
ofício, ele explicou que foi destruída quando sua casa em Lençóis pegou fogo. ${ }^{125}$ Em março de 1872, ele apresentou um memorial ao imperador no qual mais uma vez solicitou as "honras do posto" e acrescentou o pedido de "uma pensão correspondente"; novamente lamentou a "cruel enfermidade" que pusera fim a sua careira militar. ${ }^{126}$ No dia 25 de setembro de 1872, foram-lhe concedidas as honras, "em atenção aos relevantes serviços prestados na guerra contra o Paraguai". ${ }^{127}$ Talvez fosse uma recompensa pela sua atuação na mobilização de 1865 , mas se as circunstâncias da sua demissão, em janeiro de 1866, fossem conhecidas, duvido que ele tivesse sido assim tratado. Será que foi um erro da burocracia civil e militar? Ou será que Dom Obá tinha protetores na Corte? Segundo Eduardo Silva, Dom Obá era partidário dos conservadores, no poder entre 1868 e 1878, pois lhe deram um emprego; ademais, a mobilização de 1865 em Lençóis foi liderada pelos conservadores, então oposicionistas, que dominavam o município. ${ }^{128} \mathrm{Em}$ 1871-72, os capitães Marcolino e Barbosa, que certamente sabiam o que ocorrera em São Borja, estavam na Bahia e podiam ter esclarecido o caso, mas Marcolino era partidário liberal, e quanto a Barbosa, dadas as suas conexões com Carvalhal, é de supor que fosse também oposicionista. Sem mais pesquisas, essas ponderações não passam de especulações, mas é importante reconhecer a influência da política partidária, tanto na mobilização durante a guerra como na vida pós-guerra dos veteranos.

Há também lacunas curiosas nos requerimentos enviados por Galvão ao imperador através do Ministério da Guerra. De certa forma, constituem uma autobiografia do alferes, e foram aproveitados por Eduardo Silva para reconstruir a sua vida pós-guerra. No entanto, devem ter confundido as autoridades militares. Não só desobedeciam ao padrão de requerimentos militares, como também não incluíam os documentos comprobatórios (como os muitos anexados por Barbosa e Maniva, entre outros citados neste artigo). No memorial de março de 1872, alegou que "tomou parte bem ativa com esta companhia", isto é, a Terceira

\footnotetext{
${ }^{125}$ Requerimento de Galvão ao Presidente, [Salvador], 1/6/1871, AHEx/RQ, C-17-539.

126 "Memorial", 27/3/1872, AHEx, C-17-539.

${ }^{127}$ O texto desse decreto é citado por Silva, Dom Obá, p. 58.

${ }^{128}$ Silva, Dom Obá, pp. 40, 133-37.
} 
Companhia de Zuavos, "de ruidosos combates", mas como vimos, apenas as Primeira e Segunda Companhias chegaram no Sul a tempo de lutar contra a invasão paraguaia de $1865 .{ }^{129}$ É sua primeira alegação de ter participado de combates. Em 1874, Galvão solicitou novamente uma pensão, agora alegando que os ferimentos recebidos nos "diversos combates" de que participou o haviam privado de "granjear o pão" para a subsistência dele e de sua família. ${ }^{130}$ No despacho, foi instado a "instru[ir] devidamente sua petição", isto é, apresentar documentos comprobatórios. Não o fez, e entre seus requerimentos não há indício de que tivesse solicitado uma segunda via da fé de ofício queimada antes de 1871. Também não apresentou atestados de outros oficiais que soubessem do seu serviço, como o fizeram muitos dos requerentes ex-zuavos. Que Galvão nunca apresentasse documentação oficial comprobatória da sua participação nos combates de 1866, e que ele não fosse mencionado nas ordens do dia (como tantos outros oficiais das companhias de zuavos o foram), enfim, representam indícios muito fortes de que, depois da sua demissão em janeiro de 1866, ele nunca mais voltou ao serviço militar.

Se isso tudo é verdade, restam dois grandes mistérios na história de Dom Obá II: como conseguiu as honras do posto de alferes em 1872 e como criou a reputação de herói da guerra com uma fé de ofício "limpa e elogiosa", aceita pelos seus companheiros, quando havia muitos, como os capitães Barbosa e Marcolino, que sabiam a verdade e que tinham fés de ofício muito mais elogiosas do que a do alferes Galvão? Será que o respeito para com um companheiro que eles julgavam injustiçado foi o que motivou o silêncio dos capitães?

Texto recebido em 11/10/2011 e aprovado em 26/1/2012

\footnotetext{
129 "Memorial", 27/3/1872, AHEx/RQ, C-17-539.

${ }^{130}$ Requerimento de Candido da Fonseca Galvão ao Imperador, Rio de Janeiro, 16/5/1872, AHEx/ RQ, C-17-539.
} 


\title{
Resumo
}

Este artigo analisa a mobilização das companhias negras na Bahia (e em Pernambuco) durante a Guerra do Paraguai (1864-70). A organização dessas companhias racialmente segregadas era muito semelhante ao resto da mobilização brasileira, mas também remontava ao legado da milícia negra colonial e ao serviço dos seus integrantes na guerra pela Independência na Bahia. Muitos soldados e oficiais negros se distinguiram nos combates de 1866, mas o governo e o Exército brasileiros relutavam em aceitar a identidade racial implícita dessas unidades, e elas foram extintas antes do final daquele ano. Além de corrigir os muitos equívocos sobre os zuavos baianos repetidos com frequência na bibliografia acadêmica e popular, este artigo reflete sobre a complexidade da política racial na sociedade brasileira imperial e a visão negra do serviço ao Estado (e de cidadania) estreitamente ligado ao serviço militar.

Palavras-Chave: Guerra do Paraguai - zuavos baianos - política racial - recrutamento militar

\begin{abstract}
This article examines the mobilization of black regiments in Bahia (and Pernambuco) during the 1864-70 war with Paraguay. These racially-segregated companies shared many overall similarities to other military units but they also drew on the legacy of the colonial black militia and their members'patriotic service in the struggle for independence in Bahia. Many black soldiers and officers distinguished themselves in battle in 1866, but the Brazilian government and army were reluctant to accept the racial identity implied in these units, and they were all abolished by the end of the year. In addition to correcting the many misconceptions about the Zuavos that commonly appear in academic writing as well as more general literary genres, this article reflects on the complex racial politics of imperial Brazilian society and the black vision of service to the state (and of citizenship) as closely connected to military service.
\end{abstract}

Keywords: Paraguayan war - Bahian Zuavos - racial politics - military recruitment 